\title{
ADVANCING BIPARTISAN DECARBONIZATION POLICIES: LESSONS FROM STATE-LEVEL SUCCESSES AND FAILURES
}

\author{
By: \\ Renae Marshall \\ Environmental Studies, University of Colorado Boulder
}

Defense Date:

April 1, 2021

Thesis Advisor:

Dr. Matthew Burgess

\section{Committee:}

Dr. Matthew Burgess, Environmental Studies

Dr. Roger Pielke, Environmental Studies

Dr. Leaf Van Boven, Psychology and Neuroscience 


\begin{abstract}
Political polarization is at a high point in recent U.S. history and may now be the most significant barrier to coordinated national action addressing climate change. Studies of intergroup conflict suggest that collaborations pursuing shared goals can reduce polarization (and also advance the goals). In this spirit, I comprehensively review and characterize successes and failures of state-level climate legislation, focusing on opportunities for bipartisanship. I analyze 356 major state government enacted bills and 372 failed bills--aimed at decarbonization--from 2015 to 2020, as well as the political contexts in which they were passed or defeated. I use bivariate analyses, regressions, and decision trees to explore correlations and partial correlations between the policy characteristics and political contexts of bills, and their passage or failure, their bipartisanship, and the vote shares they received. Key results include: (i) Roughly one third of these state-level decarbonization bills were passed by Republican-controlled governments. (ii) Bipartisan or Republican co-sponsors disproportionately passed voluntary Property Assessed Clean Energy (PACE) programs, solar incentives, renewable energy portfolio goals, and transportation electrification; Democrat-only sponsors disproportionately passed mandatory Renewable Portfolio Standards (RPS) and emissions standards. (iii) Bills proposed in "purple" states, and those lacking explicit environmental justice components, were disproportionately enacted and bipartisan. Concerning broader framing components, bills that expand consumer or business choice and/or include financial incentives are enacted more often than those that restrict choice. Though climate change is a polarized issue, my results provide tangible insights for future bipartisan successes.
\end{abstract}




\section{Introduction}

The challenge of addressing problems at the scale and scope of climate change in a democracy requires broad, bipartisan legislative and popular support. Yet, climate change mitigation remains one of the most politically polarized issues in recent U.S. history (Iyengar and Westwood, 2014). Despite this, states are key drivers that have made efforts in recent years to increase renewable energy use and reduce carbon emissions even during a lack of climate action at the federal level. Studies to date detail state-level Renewable Energy and Efficiency (REEE) policies enacted in the early 2000's to mid 2010's with a focus on ideological framing (Hess et al., 2016), legislator characteristics and political conditions in specific state legislatures (Hess et al., 2015), interest group influence (Stokes, 2020), and insights related to political polarization. This study contributes to existing literature through comprehensively identifying recent decarbonization initiatives with both broad support and legislative intent to reduce greenhouse gas emissions, providing a broad perspective on potential bipartisan climate solutions that extends beyond carbon pricing mechanisms, and linking insights relevant to decarbonization from economics, social psychology, and political science.

Global leaders have largely failed to enact legislation ambitious enough to address climate change mitigation goals such as achieving net-zero emissions around mid-century, which is a path necessary to limit warming to below 2 degrees Celsius. Achieving these goals--deemed necessary by an overwhelming majority of the global climate science community--involves rapid decarbonization (Rockström et al., 2017). Technological advancements relating to demand response programs, energy storage from intermittent sources like solar and wind, and other energy goals are key pieces to the decarbonization puzzle (ye, 1998) along with social scientists identifying and communicating the political conditions, policy mechanisms, and ideological framing that either facilitates or presents challenges to the net-zero emissions transition. Building on previous studies and Sovacool's comprehensive meta-analysis of energy studies research and future direction in the social sciences, I analyze policy function in relation to political ideology to locate overlapping interests and goals in the polarized and often technical realm of decarbonization policy (Sovacool, 2014; Questions 5-10). This can provide helpful insights for policy-makers, organizers, and public sector decision-making processes when crafting future emissions reduction policies.

The United States' political landscape differs from other countries in the context of polarization of two major parties (Karol, 2019). At the subnational level, an important distinction should be made between states deemed as "red," that are commonly associated with conservative ideology and "blue," states, which are associated with liberal ideology. It should be noted that in recent years, the term "purple" states is used to signify swing states, or those that have similar support levels from both major parties. Despite polarization especially among legislators, public concern and support for climate change mitigation measures in the realm of energy policy has increased nationwide among registered voters from both major parties. Nearly $60 \%$ of Republican voters in a 2019 poll stated that they were worried "about the damage humans cause the planet," which has increased 10\% from five years earlier (Deutsch, 2019). A 2018 poll found 
almost $60 \%$ of young Republicans (23-38) say that climate change is having an effect on the U.S., and over $75 \%$ of voters of both parties support increasing solar and wind energy (Pew Research, 2018). A 2017 study found majority support among Republicans for regulating CO2 as a pollutant in every state except Wyoming (Mildenberger et al., 2017). While it is difficult to find majority support for high-level concerns, climate change-related policies can get two-thirds support for more specific statements and state policies such as net metering and energy efficiency mandates (National Surveys on Energy and Environment, 2017), support for taxing corporations based on their carbon emissions (Tyson and Kennedy, 2020), and support of states requiring an increased use of renewable energy through Renewable Portfolio Standards (National Surveys on Energy and Environment, 2018) to name a few.

Scientists' climate concerns became part of mainstream media conversation in the 1980s, ushering a public attitude shift and a new issue for politicians on both sides of the aisle to take note of. Landmark legislation to protect air and water passed under Nixon's Administration about a decade prior, along with the establishment of the Environmental Protection Agency to enforce these acts, and others. With increasing concern in the climate science community, the environmental conversation expanded to include the contribution of anthropogenic greenhouse gas emissions to uncharacteristic warming on a global scale. Climate change was featured on the cover of the New York Times in 1981 and NASA scientist James Hansns urged the Senate Energy Committee to act in his 1988 testimony (Worland ,2017). Evidence of bipartisan recognition and support for climate change mitigation on the presidential stage dates back to 1988 when former Republican president, George H.W. Bush brought the new issue to light on the Michigan campaign trail. From a congressional lens, Representative Claudine Schneider (R-RI) proposed the Global Warming Prevention Act of 1988 aimed at establishing national policies that support energy conservation, international agreements, and actions to reduce warming (H.R.5460, 1988). This legislation never passed the introduction stage, but illustrates that some Republican lawmakers had climate change mitigation on their agendas in previous decades.

\section{$\underline{1.1}$ Challenges to Past Bipartisanship}

Over the last three and a half decades, the climate science community has become increasingly united and certain of the causal relationship between anthropogenic greenhouse gas emissions and increasing severity of climate change. At the same time, it became one of the most divisive political issues in recent U.S. history (Iyengar and Westwood, 2014; Milman, 2019). Bipartisanship on climate mitigation measures has faced significant, documented challenges especially over the last decade, including: (1) interest group influence (2) ideological clashes, (3) and increasing tribalism in the political landscape.

\subsubsection{Interest Group Influence}

Interest group influence is a key aspect of polarization on environmental issues from public and legislative perspectives. Though climate change issues especially related to clean energy achieved public support across the aisle in the early to mid 2000's, between 2008 and 
2011, belief in climate change decreased dramatically among Republicans (Mildenberger and Leiserowitz, 2017). Similarly, Republican legislators openly supported clean energy dating back to the late 1980's and 1990's, however this position has shifted since around 2010 when interest groups such as the Koch Industries made examples out of Republicans who were climate champions, and in some cases successfully primaried them (Leonard, 2019). This shift is a result of three related forces. First, fossil fuel companies and utilities played a big role in driving elite polarization when they realized that profits were taking a hit after widespread renewable energy uptake in the form of primarily net metering and Renewable Portfolio Standards legislation throughout the 2000's and early 2010's. This led to efforts to retrench existing state level clean energy policies, or to block them altogether through an assortment of tactics including direct lobbying contributions and primarying Republican climate champions. The threat of a primary challenger has been enough to pressure some Republicans to realign their positions on climate and clean energy issues. Over twenty states have expanded their Renewable Portfolio Standards, while others have failed to enact them altogether or have severely retrenched their goals in recent years (Stone, 2020).

In addition to this realization, anti-environmental interest groups, namely fossil fuel corporations and some public utilities are highly connected and able to quickly mobilize across state boundaries to directly target legislators (especially from the Republican party) and weaken current policies through regulatory and judicial means (Stokes, 2020; Brulle, 2014; Dunlap and McCright, 2011). These groups far out compete pro-renewable energy and other environmental interests in terms of financial resources and efficient information-sharing networks. The presence of special interest lobbying in climate policy is qualitatively evident, though quantifying precise influences has presented challenges in a political landscape where anti-climate legislation interest groups utilize loopholes or fund certain organizations through a back-door approach (Meng and Rode, 2019). Thirdly, interest groups weaponize public opinion by drumming up climate denial and anti-renewables public campaigns. When clean energy advocates are pushing for renewable energy policies, companies like Exxon Mobil and Koch-affiliated groups draw the existence of human-driven climate change and the validity of climate science into a public debate--and they have been doing so dating back to the 1980's (Stokes, 2020). Renewable energy (specifically onshore wind and solar PV) is now cheaper than any fossil fuel without financial assistance (Ellsmoor, 2019), though there are still significant, entrenched interests fighting to stall adoption.

Figure 1 shows contributions from the oil and gas industry and electric utilities from 1990-2020 disproportionately go to Republican candidates (FollowtheMoney.org, 2020). The Kyoto Protocol is an international treaty which commits participating countries to reduce greenhouse gas emissions. There is a clear uptick of donations to candidates from both parties after this and an even more dramatic increase after Citizens United vs. FEC. This ruling freed labor unions and corporations to finance electioneering communications and openly advocate for the success or defeat of a given candidate (Dunbar, 2012). The contribution numbers come from local, state, and national data and show that a sharp increase in contributions happened in the 
mid-2000's. Data from the Center for Responsive Politics dating back to campaign contributions from 1990 supports this recent trend, showing that donations from environmentalists overwhelmingly go to Democratic candidates, while donations from oil, gas, and coal companies go to GOP candidates (Karol, 2019; $\underline{\text { Center for Responsive Politics: Industry Profile). }}$

Figure 1: Financial contributions to Candidates by Party (Oil \& Gas and Electric Utilities) from 1990-2020

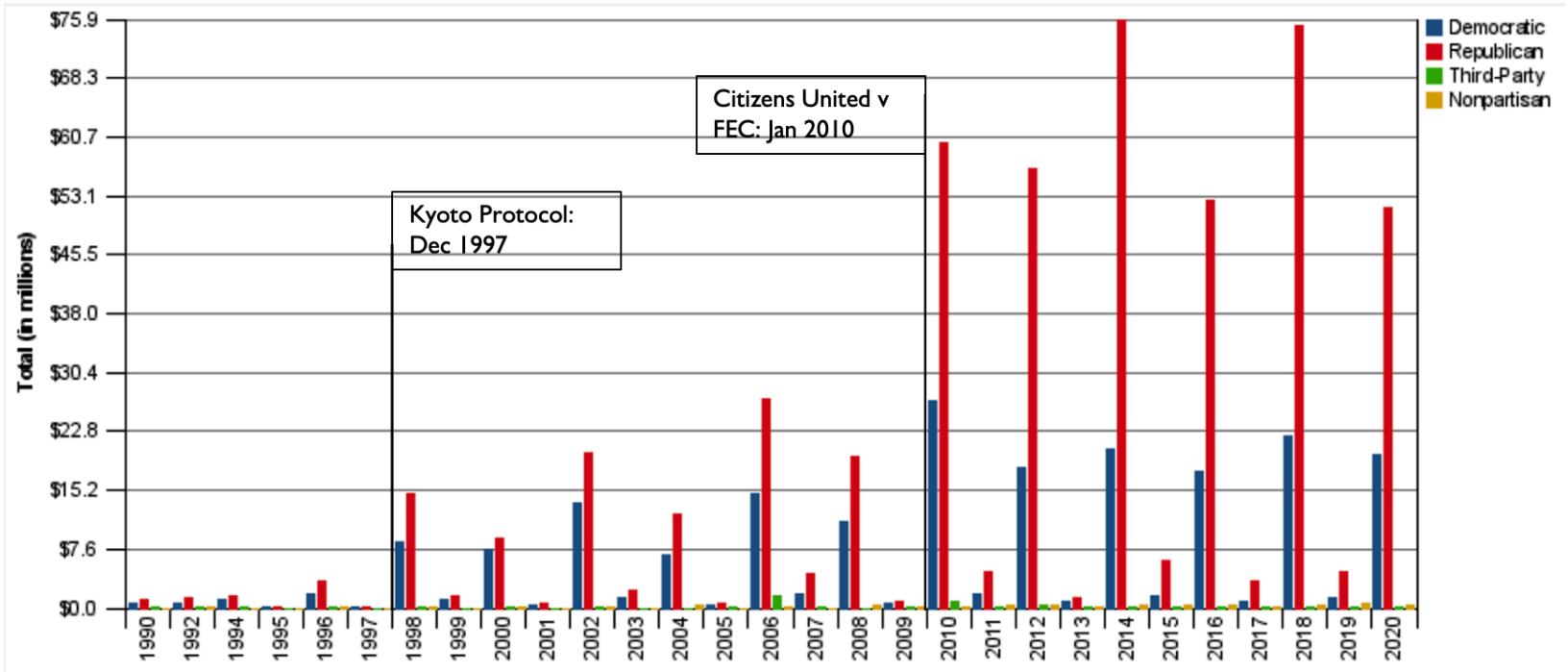

\subsubsection{Polarization is Tribalism and Ideological Differences}

Understanding political polarization in the U.S. on any issue requires a combination of tribal and ideological contributions. Evidence for tribal psychology is found in every known human society (Brown DE, 1991) and presents very early on in childhood (Feinman and Entwisle, 1976; Bar-Haim et al., 2006). The composition of a person's tribe is culturally malleable, but the instinct to belong to groups is a universal human characteristic. In-group favoritism (Iyengar, Sood, \& Lelkes, 2012) and outgroup hostility (Mackie, 1986) are features of tribal behavior that arise in other contexts (Iyengar and Westwood, 2014), and are documented barriers to effective climate policy (Van Boven et al., 2018). In addition to tribal psychology and behavior, there is also a real difference, on average, in the moral foundations of conservatives and liberals that contributes to polarization (Haidt, 2012; Hess et al., 2016). One of the most documented differences is the acceptable role of government intervention, which extends to disagreements in many policy areas including environmental policy (Kulin and Seva 2019; Hess et al. 2015). For example, people who identify as liberals are more likely to support intervention through public spending and taxation across a variety of domains than their conservative counterparts, especially in areas such as the labor market and social welfare ( $\underline{\text { Jaeger 2006 }}$ ). Tribalism and underlying ideological clashes contribute to the current polarization around environmental issues.

Although it has not always been the case, politics have become the dominant axis of tribalism in the U.S. (e.g., Iyengar et al., 2012). Only about six percent of marriages in the U.S. are between members of opposing parties according to a recent 2020 study (Fund, 2020) and 
political partisanship has become even more polarizing than race and religion (Iyengar et al., 2012). Political party identification has increasingly become the key to people's identity (Mason, 2016). First, this causes perverse and irrational trends that can make policy ideas from either party fail or be less effective because of disdain for who proposed them. This phenomenon is called affective polarization, which is when people feel increasingly negative towards members of the other party (Pew Research, 2016; Pew Research, 2014; Iyengar et al., 2019).

Well-connected interest groups and denial campaigns are one piece of the polarization story, though it should also be viewed through the lens of elites. A recent study argues that outgroup cue-taking from Democrat elites is also a main cause of climate denial, and in turn polarization on climate policy (Merkley and Stecula, 2020).

Issue framing is another contributor to tribal behavior. Studies show that members follow when their party's framing shifts, though not completely blindly due to their previous experiences and pre existing values (Slothuus, 2010). For example, one study found that the relationship between partisan cues and climate policy support are mediated by the normative in-group perceptions of other Democrats and Republicans (Van Boven et al. 2018). When frames are sponsored by parties, they have greater influence on contentious issues (Slothus and de Vreese, 2010). Lastly, the recent fractured media landscape has contributed to tribal behavior through cultivating opportunities for web personalization, confirmation bias, and echo chambers of like-minded individuals (Mitchell et al., 2014; Sunstein, 2018). In a study including social network analyses of 78,753 Twitter accounts followed by U.S. senators, Helmuth et al. discuss the strong link between political polarization and the role that climate science, which is mostly dominated by liberal individuals, plays in context of the political process (Helmuth et al., 2016).

Polarization can also be explained by key differences in moral foundations of liberals and conservatives. Drawing on decades of research in moral, evolutionary, and social psychology, Dr. Jonathan Haidt helped develop the Moral Foundations Theory. In his book, The Righteous Mind, he describes morality as a "tongue with 6 different moral taste buds" (Haidt, 2012). Although humans have the same taste buds, we like and dislike different foods. One of the six moral taste buds that liberal psychology is closely aligned with is Care/Harm, while one of the mentioned conservative alignments is with the Liberty/Oppression instinct (Haidt, 2012). He found that liberals and conservatives are activated by different cues related to Liberty/Oppression. Liberals framed this in terms of group-level oppression; conservatives framed it in terms of threats to individual liberty (Haidt, 2012). These core moral foundations can contribute to the kinds of policies that each party is more likely to support. An overarching example of this is the idea that environmental issues are often seen as a project of big government through the conservative lens, which threatens the Liberty/Oppression foundation that opposes excessive governmental powers. On the other hand, liberals may be more likely to support legislation with a focus on environmental justice, which potentially activates their Care/Harm taste buds. However, there are many different kinds of renewable energy and emissions reductions policies that vary with respect to governmental control. There is room for flexibility in decarbonization policy design (Elliott, 2019). 
A previous study identifies policies at the state level from 2008-2014 that do not trigger opposition to conservative values such as tax reductions, reducing regulation, or voluntary renewable energy portfolio goals are likely to pass with the most support given the metric of percentage of yes votes in the lower house and assemblies of a 16 state subset. This finding is supported by a study focusing on the California state legislature from 2011-2012 (Hess et al. 2015), where Republican votes were least likely to be cast for renewable energy legislation, energy efficiency policies, increased regulations for businesses, or a government spending increase. Both studies highlight the nuance inherent to different kinds of decarbonization policies regarding support from Republican legislators.

\subsection{Overcoming Challenges}

It is well known that Democrat legislators support climate legislation more often than their Republican counterparts and that climate mitigation legislation related to decarbonization policy has disproportionately stalled in the Republican party as a result of both interest group influence and cues from prominent elite Democrats (Stokes, 2020; Karol, 2019). Under Republican leadership over the last four years, the U.S. stood out as an outlier after the Trump administration pulled out of the Paris Climate Accord that pursues efforts to limit global temperature increase to $1.5 \mathrm{C}$ this century (McGrath, 2020). The Clean Power Plan was repealed in 2019 in addition to 112 Obama-era pro environmental rules since 2016 (Popovich et al., 2021). The time frame of the study beginning in 2015 marks a significant shift in the political landscape regarding multiple policy areas. More broadly, this is around the time when political polarization seemed to shift into overdrive.

Political polarization is clearly pronounced in U.S. politics--especially related to climate action--though studies show that there are potential ways to overcome this. Cooperation in pursuit of shared goals is one way that we can overcome tribal behavior (Pettigrew, 1998). Seeds of this cooperation are present at the federal level though the bipartisan House and Senate Climate Solutions Caucuses that were sparked by members from both parties in 2016 and 2019 respectively and focus on facilitating solution-oriented discussions on climate change (Citizens' Climate Lobby, 2021). During the same time period where climate legislation at the federal level was either rolled back or blocked, multiple carbon tax bills reached the House floor with bipartisan support for four out of the seven. Carbon taxes are praised by some conservative elites as a way to tax and incentivize firms to reduce emissions without triggering conservative concerns of increased governmental regulation or mandates (Climate Leadership Council, 2017). Another recent study shows that a coalition-building approach that couples certain economic and social policies with climate policy can increase climate action support from a public opinion standpoint (Bergquist et al., 2019).

State-level decarbonization action encompasses a broad range of initiatives beyond carbon pricing mechanisms and presents opportunities for bipartisanship that are not as prevalent at the federal level. Legislation has been introduced and enacted in various degrees across the fifty state legislatures with differing levels of support from Democrats and Republicans since 
2015 (Advanced Energy Legislation Tracker, 2021). While a majority passed in Democrat-controlled state legislatures, there are a number of notable exceptions that passed in historically red states.

Figure 2: Notable legislation passed in historically red or purple states

\begin{tabular}{|c|c|c|c|}
\hline State & Bill ID & $\begin{array}{l}\text { Year } \\
\text { Enacted }\end{array}$ & Function \\
\hline AR & SB 145 & 2019 & $\begin{array}{l}\text { Solar Access Act: Allows solar leasing and third-party purchasing and triples the max solar size } \\
\text { limit for businesses }\end{array}$ \\
\hline $\mathrm{FL}$ & $\mathrm{HB} 195$ & 2016 & $\begin{array}{l}\text { Exempts the assessed value of renewable energy devices from the real property tax and the } \\
\text { tangible personal property tax. }\end{array}$ \\
\hline FL & SB90 & 2017 & $\begin{array}{l}\text { Extends a renewable-energy tax break to commercial and industrial properties and makes } \\
\text { renewable-energy equipment exempt from state tangible personal property taxes. }\end{array}$ \\
\hline GA & HB57 & 2015 & Legislature may approve solar panel lease financing. \\
\hline IA & HF645 & 2015 & $\begin{array}{l}\text { Increases lowa's solar energy tax credits and adds production tax credits for utility solar } \\
\text { projects. }\end{array}$ \\
\hline SC & $\underline{\mathrm{H} 3659}$ & 2019 & $\begin{array}{l}\text { Energy Freedom Act: Supports a more resilient, clean energy future by supporting solar PV and } \\
\text { battery storage technologies. }\end{array}$ \\
\hline SC & HB3874 & 2015 & Provides a tax credit to individuals and businesses that install geothermal \\
\hline UT & HBI5 & 2015 & Extends Utah's current AFV tax credit program \\
\hline UT & HB4II & 2019 & $\begin{array}{l}\text { Provide cities with mechanisms to establish and achieve a community goal to source net- } 100 \% \\
\text { of electric energy from renewable resources by } 2030 \text {. }\end{array}$ \\
\hline
\end{tabular}

\subsection{Hypotheses}

Taking ideological differences, tribal behavior, and the gravity of decarbonization goals into account, here I analyze over 750 state level decarbonization bills using variables such as classification to understand bill function and the presence or absence of components (expanded choice, financial incentives, and environmental justice) to challenge seemingly insurmountable polarization. The overarching motivation of this research is to draw inspiration from bright spots and areas of hope for future legislative bipartisanship on climate mitigation policies, specifically decarbonization of the energy and transportation sectors. This study provides a comprehensive view of state-level decarbonization policy since 2015. It (1) identifies decarbonization policies passed with both bipartisan and uni-party sponsors at the state level since 2015, (2) examines policy design components and/or political conditions where bills pass significantly more or less often (conditional on them being proposed in the first place), and (3) identifies specific characteristics of bipartisan-sponsored legislation. I investigate the following hypotheses:

Hypothesis 1: Decarbonization policy, both uni-party and bipartisan-sponsored, passes more often under Democrat-controlled state legislatures.

Hypothesis 2: Legislation that includes mandatory standards, regulations, and restrictions have the lowest support levels, are enacted least frequently, and pass less often with bipartisan support. 
Hypothesis 3: Legislation that introduces voluntary portfolio goals, increases financial benefits for transitioning away from fossil fuel-based energy sources, or expands individual and/or business choice in the context of this energy transition will pass more often with bipartisan support.

Hypothesis 4: Legislation that includes an environmental justice component will receive bipartisan support more often when it includes economic redistribution opportunities than when it focuses on a 'critical theory' framing approach, which we define operationally for our analysis according to whether bills use specific terminology associated with critical theories in academia (George, 2021).

\section{Methods}

\subsection{Decarbonization Policies In Context}

Decarbonization policies vary in complexity, function, and design. I use a combination of analyses from the dataset I compiled, coupled with a review of grey literature and legislative reports, to examine patterns in enacted and failed legislation. For the purposes of this study, 'decarbonization initiatives,' refers to any policy that has either a stated intention or documented effect of reducing greenhouse gas (GHG) emissions or the GHG-emission intensity of an economic activity. A number of policy types that seek to mitigate climate change exist, as well as policies that are detrimental to climate mitigation goals during the 2015-2020 time frame (Ohio $\underline{\text { HB6}}$ and West Virginia HB2001 are some examples of detrimental legislation that passed; I do not include detrimental policies in my analysis). I include major legislation that has passed or failed in this time frame and exclude less ambitious bills (e.g. a minor definition change, a small change in legislative language that does not strengthen or retrench the original bill). Thus, I focus on majors bills aimed at decarbonization. I define bills as 'bipartisan,' if they attract co-sponsor(s) from the opposing party or result in unanimous vote shares in a state's lower assembly.

In the spirit of the analysis by Hess et al. (2016), I use similar bill searching criteria and categories, with some changes. First, this dataset includes policies relevant to decarbonizing the transportation sector from the perspectives of advanced vehicle adoption incentives, supporting infrastructure, and alternative fueling incentives. It also includes GHG emissions standards (separate from renewable energy standards) and any policies that divest from fossil fuel energy sources or shut down polluting sources. This dataset uses The State Policy Opportunity Tracker from Colorado State University Center for New Energy Economy as a default to determine classifications for bills that do not cleanly fit into the pre-existing categories (SPOT, 2021). Green text in Table $3 \mathrm{~b}$ indicates an added category or component that was not originally included in the Hess et al. (2016) classification criteria, but is relevant to decarbonization goals since 2015. 


\subsection{Dataset Creation}

I compile two datasets using publicly available policy documents available through the Advanced Energy Legislation Tracker. I read each bill and cross checked with resources such as Legiscan, legislative reports on state government websites, and press releases when available. The first includes 356 enacted decarbonization bills from 2015 through 2020 (with the exceptions of two states due to lack of available vote share data), and the second includes 752 both enacted and failed bills. Additionally, there are a number of states (16) where I originally expected to find a large amount of failed bills, but did not find any. This is likely because there are hundreds if bills that are in the "introduced," stage in these states, so determinations cannot be made about their overall success or failure (ie. Texas has 500 introduced bills spanning from 2015-2020). The enacted dataset includes one variable that is not present in the enacted and failed dataset--percentage of "yes" vote share given that a large majority of the failed bills did not make it to a vote. With the exception of the vote share variable, all others remain consistent between datasets. Using the classification scheme as described below, I create three variables to measure components of policies that are present across classifications--the presence or absence of a financial incentive, expanded choice, and environmental justice components. These variables record bill functions that are either not fully captured by the classification scheme or that are not the main focus, but important aspects of a particular bill.

Financial Incentive: Includes two levels (yes, no). Bills either introduce an incentive (ie., renewable energy or alternative fueling tax credit, fee reductions, tax exemptions, require shared renewable financing, Property Assessed Clean Energy (PACE) laws, and create/disperse funds for renewable energy projects) or do not (ie., regulatory adjustments, emissions standards and renewable energy portfolio standards (RPS) without financial incentives, and others).

Expanded Choice: Includes three levels (yes, no, no effect). Expanded choice (yes) bills do not have a mandate and either create a positive reinforcement or new options for individuals and businesses that did not exist before. Second, expanded choice (no) bills that create penalties, restrictions, and/or new regulations restrict choice. Lastly, this variable includes bills that have no effect on individual or business choices.

Environmental Justice: Includes three levels (economic frame, critical theory frame, and no environmental justice component). Bills with an economic frame of environmental justice explicitly center low-income communities in terms of benefits from renewable energy or emissions reduction programs, and does not explicitly center communities on the basis of race, sex, or other immutable characteristic. Such policies can include specific funds from cap and trade programs, community solar and other shared renewable initiatives, and specific tax incentives and rebates for new technologies related to electric vehicles, to name a few. For our purposes, 'critical-theory-framed' legislation either explicitly centers communities based on race, sex, or another immutable characteristic, or explicitly invokes one of the terms: "justice" (in a 
context not directly related to criminal law), "environmental justice", or "marginalized." Examples include establishing a permanent environmental justice commission or creating penalties for industry in the face of disproportionate impact of pollution and toxic chemicals on racial minority communities. Bills without an environmental justice component were coded as "no justice." Other variables relate to the conditions under which each bill was passed including state legislature control, the political status of the state, and the levels of sponsorship related to each party.

Table 3a: Variable Descriptions

\begin{tabular}{|c|c|}
\hline State and Bill ID & $\begin{array}{l}\text { Bill ID: Specific to each bill } \\
\text { State: NH, HI, MA and specific bills from MD, ME showed no voting } \\
\text { records. None found for OK, SD. }\end{array}$ \\
\hline $\begin{array}{l}\text { State Legislature } \\
\text { Control }\end{array}$ & $\begin{array}{l}\text { Red or blue trifecta: Governor, and both Senate and Assembly are } \\
\text { from one party } \\
\text { Red or blue majority: Two out of the three are from one party }\end{array}$ \\
\hline State Political Status & $\begin{array}{l}\text { Red, Blue or Purple: Based on majority party control from 2015-2020. } \\
\text { If the party control fluctuates, then the state is considered "purple." } \\
\text { (Detailed chart in } \underline{\text { Appendix 1). }}\end{array}$ \\
\hline $\begin{array}{l}\text { Spectrum Sponsors } \\
\text { (as determined by } \\
\text { AEL tracker and } \\
\text { Legiscan) }\end{array}$ & $\begin{array}{l}\text { - If } 50 \%-60 \% \text { of sponsors are from one party, we consider the bill } \\
\text { 'Bipartisan' } \\
\text { - If } 61 \%-75 \% \text { of sponsors are from one party, we consider the bill } \\
\text { 'Slight Partisan (D or R)' } \\
\text { - If } 76 \%-90 \% \text { of sponsors are from one party, we consider the bill } \\
\text { 'Moderate Partisan (D or R)' } \\
\text { - If } 91 \%-100 \% \text { of sponsors are from one party, we consider the bill } \\
\text { 'Strong partisan (D or R)' }\end{array}$ \\
\hline SPOT Tracker & Provides broad categories of bill characteristics. (See table $3 \mathrm{~b}$ ) \\
\hline Classification & Provides further classification of bill function (See table $3 b$ ) \\
\hline
\end{tabular}

Table $3 b$ SPOT Categories and Further Classification

\begin{tabular}{|c|c|c|c|c|}
\hline $\begin{array}{l}\text { Emissions, } \\
\text { Infrastructure, } \\
\text { Grid, and Rate } \\
\text { Policies }\end{array}$ & $\begin{array}{l}\text { Energy } \\
\text { Efficiency } \\
\text { Policies }\end{array}$ & $\begin{array}{c}\text { Financing and } \\
\text { other energy } \\
\text { incentive } \\
\text { policies }\end{array}$ & $\begin{array}{c}\text { Transportation } \\
\text { Policies }\end{array}$ & $\begin{array}{c}\text { Renewable Energy } \\
\text { Policies }\end{array}$ \\
\hline $\begin{array}{c}\text { Emissions Standard } \\
\text { Energy Storage }\end{array}$ & $\begin{array}{l}\text { Building } \\
\text { Efficiency }\end{array}$ & $\begin{array}{c}\text { PACE laws } \\
\text { Other Financial }\end{array}$ & $\begin{array}{l}\text { Transportation: } \\
\text { EV or ZEV and } \\
\text { supporting }\end{array}$ & $\begin{array}{c}\text { Net metering } \\
\text { REEPS }\end{array}$ \\
\hline
\end{tabular}




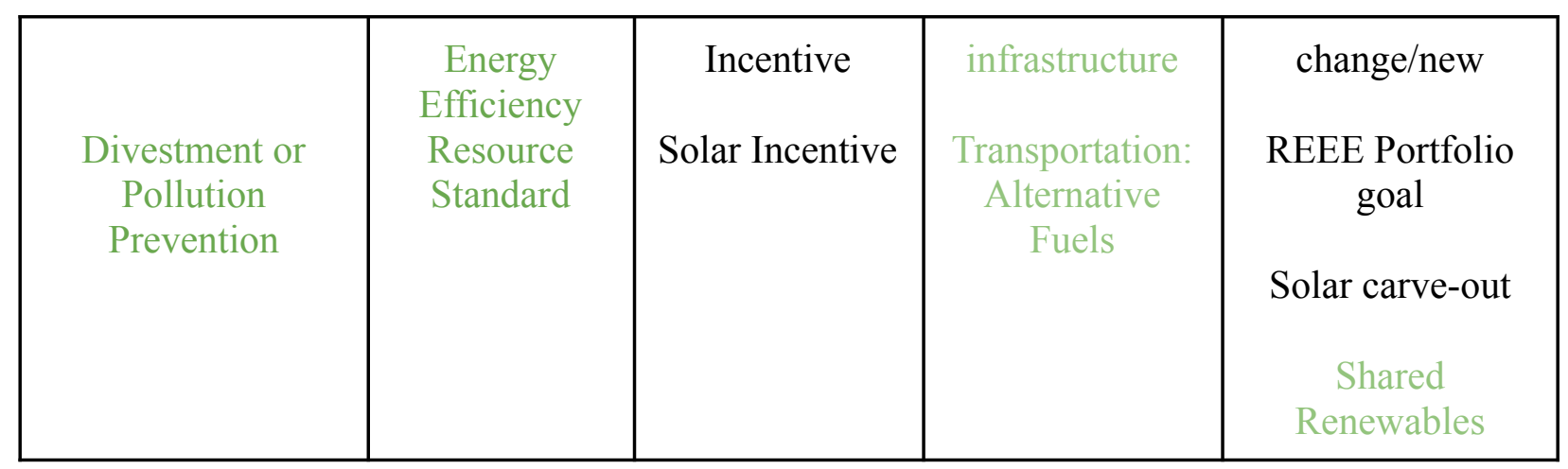

Classifications including Authorization, Other REEE, and Reduces Regulation, span across all categories. Green text indicates classifications that are not covered by Hess et. al., 2016, but are relevant to decarbonization goals since 2015. **See Appendix 3 for more on bill classifications.

\section{$\underline{2.3}$ Overview of analyses}

I explore correlations and partial correlations between policy characteristics and political contexts of bills using metrics of bipartisanship, vote share, and their passage or failure.

The initial bivariate analysis focuses on the question of bipartisanship using the following measures: (1) high vote share and (2) bipartisan sponsorship. Specifically, this analysis identifies which bill types and broader components receive these metrics more so than others. I group Republican and bipartisan-sponsored bills together, under the assumption that Democrats almost always vote in favor of decarbonization policy and Republican support is usually the limiting factor in bipartisanship. Indeed, vote share patterns bear this out.

My regression analysis focuses on the question of which bill characteristics partially correlate with higher success rates in terms of passage. I use general linear models (GLM) and decision trees for each SPOT tracker category (1. Emissions, Infrastructure, Grid, and Rate Policies, 2. Energy Efficiency Policies, 3. Renewable Energy Policies, 4. Financing and other energy incentive policies, 5. Transportation) to understand these correlations. The GLM shows instances where bills pass more or less often in addition to passage with bipartisan co-sponsors (enacted and bipartisan) in the presence or absence of broad bill components, "red," "blue," or, "purple," political conditions, and SPOT category, while holding the year and state variables constant. The decision tree models include passage as the response variable and financial incentives, expanded choice, environmental justice, and state political status as the predictor variables. The partitioning method on JMP software searches "all possible splits of predictors to best predict the response" (JMP Predictive and Specialized Modeling, 2021). A validation level of 0.20 was set to prevent overfitting and a cross validation report was produced for each tree. This analysis was performed using R Studio and JMP software. 


\section{Results}

Key results include: (i) Around one third of the analyzed bills passed in Republican-controlled state legislatures. (ii) Bipartisan or Republican co-sponsors disproportionately passed bills with expanded choice and financial incentive components, and without environmental justice. Specific policies include voluntary Property Assessed Clean Energy (PACE) programs, solar incentives, renewable energy portfolio goals, and authorization; Democrat-only sponsors disproportionately passed bills that restrict choice, do not have financial incentive components, and include both environmental justice frames. Specific policies include mandatory Renewable Portfolio Standards (RPS) and emissions standards, among others (see Figure 6). Vote share patterns overwhelmingly reflect these patterns. (iii) Bills proposed in "purple" states, those including expansion of individual and/or business choice, and those lacking explicit environmental justice components, were disproportionately enacted and disproportionately bipartisan.

\subsection{High-Level Patterns and Measures of Bipartisanship}

The following high-level patterns emerge in this analysis. First, decarbonization bills are visibly enacted more frequently under Democrat-controlled state legislatures (Figure 4). However, approximately one-third passed in either Republican majorities or trifectas, signaling support of certain decarbonization policies in areas where there has been historic and significant resistance. Another key pattern relates to vote share. Democrats almost always vote for climate bills, along with a smaller cohort of Republicans. Figure 5 shows that a larger amount of bills pass narrowly in the Democrat sponsorship condition, while they pass overwhelmingly by Republican and bipartisan sponsors.

Figure 4: Distribution of Enacted Decarbonization Bills

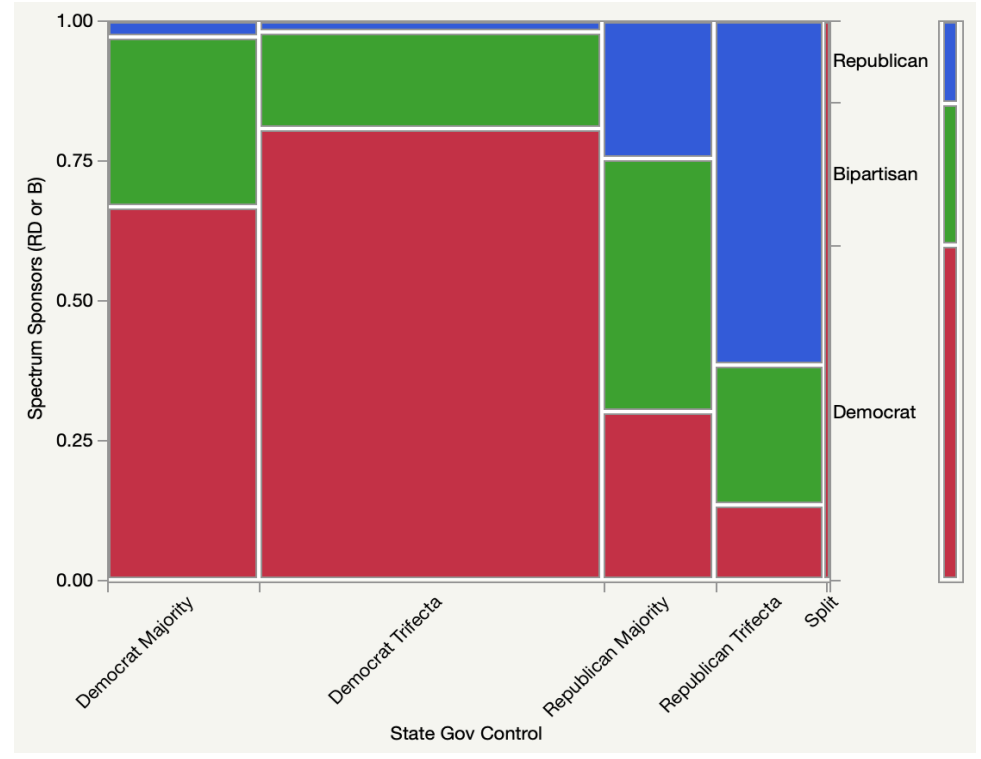


Figure 5: Vote Share and Co-Sponsorship

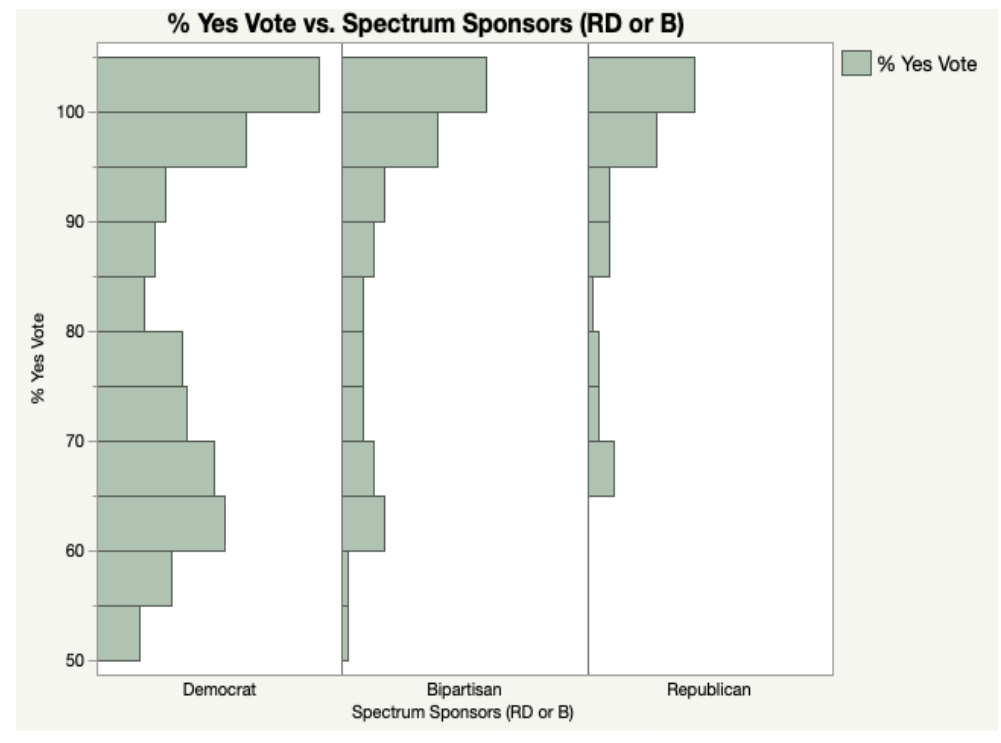

Figures $\underline{6}$ and $\underline{Z}$ indicate the percentage of a certain bill classification or overarching component of the total enacted bills by sponsorship, in addition to the associated vote shares. Bipartisanship can be defined in different ways, but is often understood in terms of vote share, sponsorship, and levels of collaboration between parties in the policymaking process (Mekelburg, 2020). For the purposes of this analysis, I used the former measures to show trends in policies that include bipartisan versus uni-party sponsors and the associated vote shares to measure the legislative popularity of certain issues. Positive slopes indicate a higher level of passage by bipartisan or Republican sponsors, and negative slopes indicate a higher passage level among Democrat-sponsored bills. Cap and trade, transportation (both related to alternative fuels and electric vehicle incentives and infrastructure), shared renewables, building efficiency, net metering, and new (or stricter) emissions standards or Renewable Portfolio Standards make up a higher percentage of all Democrat-sponsored bills. Similarly, bills that authorize an action, reduce regulatory barriers, provide solar and other financial incentives, enact Property Assessed Clean Energy (PACE) laws, and set non-mandatory utility portfolio goals passed disproportionately with bipartisan or Republican cosponsors. A previous study (Hess et al. 2016), found that new or stricter RPS received the least amount of support from a vote share perspective in comparison to other policies, which is supported by this analysis. 
Figure 6: Bipartisan Support by Bill Classification

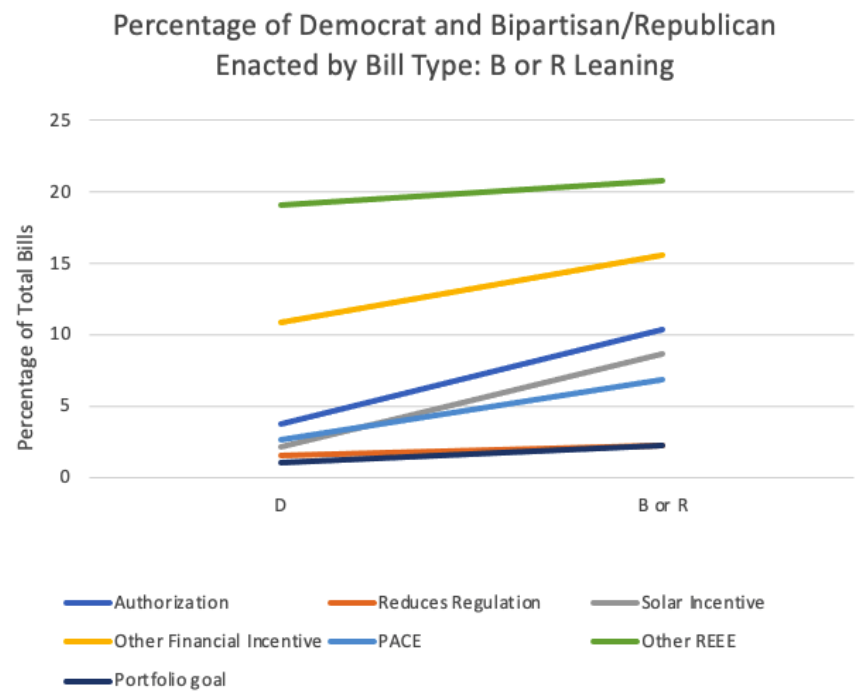

Percentage of Democrat and Bipartisan/ Republican Enacted by Bill Type: Democrat Leaning

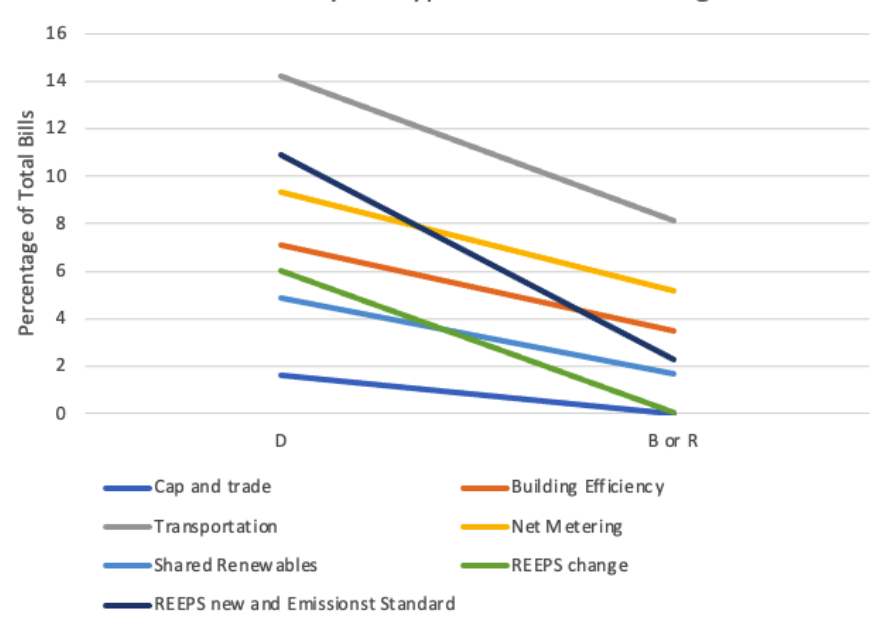

Classifications are compared to the highlighted, "REEPS change" category for purposes of determining significance.

\begin{tabular}{|c|c|c|}
\hline Bill Type & $\begin{array}{l}\text { Number } \\
\text { of Bills } \\
\text { Passed }\end{array}$ & $\begin{array}{l}\text { \%Yes Votes, } \\
\text { Lower House, } \\
\text { Both Parties }\end{array}$ \\
\hline Authorization & 25 & $91 * *$ \\
\hline Reduces Regulation & 7 & 91.9 \\
\hline $\begin{array}{l}\text { Divestment or Pollution } \\
\text { Prevention }\end{array}$ & 12 & 88.1 \\
\hline Emissions Standard & 13 & $69.7 * *$ \\
\hline $\begin{array}{l}\text { Energy Efficiency } \\
\text { Resource Standard }\end{array}$ & 3 & 81 \\
\hline PACE laws & 17 & $90.9 *$ \\
\hline Net metering & 23 & 84 \\
\hline Other Financial Incentive & 47 & $88.5^{*}$ \\
\hline Solar Incentive & 19 & 87.6 \\
\hline Building Efficiency & 19 & 84.6 \\
\hline REEE portfolio goal & 6 & 76.6 \\
\hline REEPS new & 10 & $64^{* * *}$ \\
\hline Shared Renewables & 13 & 79.3 \\
\hline Energy Storage & 12 & 88.5 \\
\hline Cap and trade & 3 & $63.7 *$ \\
\hline $\begin{array}{l}\text { Transportation: } \\
\text { Alternative Fuels }\end{array}$ & 16 & 84.6 \\
\hline Transportation: EV & 28 & 82.4 \\
\hline Other REEE & 71 & $87.4^{*}$ \\
\hline REEPS change & 13 & 83.5 \\
\hline Summary & 356 bills & 82.4 (mean) \\
\hline \multicolumn{3}{|l|}{$*_{p}<0.05$} \\
\hline \multicolumn{3}{|l|}{$* * p<0.01$} \\
\hline $\begin{array}{l}* * * \mathrm{p}<0.00 \mathrm{I} \text {, bivariate } \\
\text { comparison with REEPS } \\
\text { change }\end{array}$ & & \\
\hline
\end{tabular}


Figure 7: Bipartisan Support by Bill Classification.

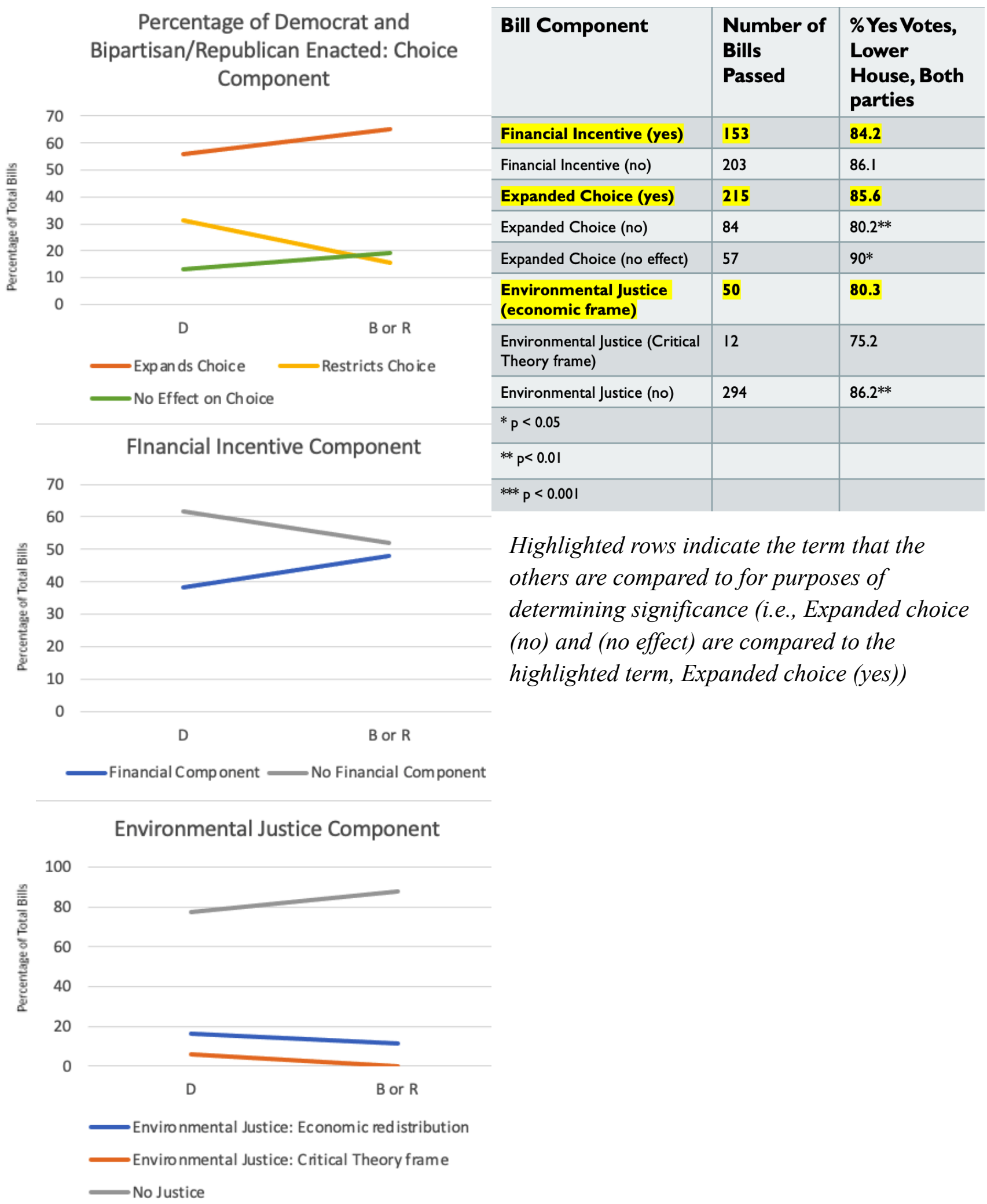




\section{$\underline{3.2}$ Likelihood of Passage and Decision Trees}

Table 8: Generalized Linear Models

\begin{tabular}{|c|c|c|c|c|c|c|c|c|}
\hline Term & Enacted I & $\begin{array}{l}\text { Enacted and } \\
\text { Bipartisan I }\end{array}$ & Enacted 2 & $\begin{array}{l}\text { Enacted and } \\
\text { Bipartisan } 2\end{array}$ & Enacted 3 & $\begin{array}{l}\text { Enacted and } \\
\text { Bipartisan } 3\end{array}$ & Enacted 4 & $\begin{array}{l}\text { Enacted and } \\
\text { Bipartisan } 4\end{array}$ \\
\hline Intercept & $-0.36(0.18)^{*}$ & $-1.81(0.3)^{* * *}$ & $-0.27(0.17)$ & $-1.61(0.28)^{* k * *}$ & $-0.16(0.16)$ & $-1.7(0.27)^{\text {*k*k }}$ & $0.03(0.08)$ & $-1.17(0.1)^{* * * *}$ \\
\hline $\begin{array}{l}\text { Financial } \\
\text { Component: } \\
\text { Yes vs. No }\end{array}$ & $-0.07(0.1 \mathrm{I})$ & $0.18(0.13)$ & $-0.09(0.1)$ & $0.16(0.11)$ & $0.13(0.10)$ & $0.32(0.12)^{* * *}$ & - & - \\
\hline \multicolumn{9}{|l|}{$\begin{array}{l}\text { Political Status: Blue } \\
\text { and Purple vs. Red }\end{array}$} \\
\hline Purple states & $0.33(0.13)^{* * k}$ & $0.39(0.14)^{* * *}$ & $0.32(0.12)^{* *}$ & $0.35(0.13)^{*}$ & $0.21(0.13)^{*}$ & $0.38(0.14)^{* *}$ & - & - \\
\hline Blue states & $\begin{array}{l}0.38 \\
(0.11)^{\text {*ak* }}\end{array}$ & $-0.38(0.12)^{* * *}$ & $0.33(0.12)^{* *}$ & $-0.36(0.12)^{* *}$ & $0.33(0.10)^{* *}$ & $-0.4(0.12)^{* * * *}$ & - & - \\
\hline \multicolumn{9}{|l|}{$\begin{array}{l}\text { Expanded Choice: } \\
\text { Yes and No Effect } \\
\text { vs. No }\end{array}$} \\
\hline Yes & $\begin{array}{l}0.95 \\
(0.14)^{\text {*kokk }}\end{array}$ & $0.28(0.16)$ & $0.35(0.13)^{\text {*k* }}$ & $0.57(0.15)^{* * 1 * *}$ & - & - & - & - \\
\hline No Effect & $0.08(0.16)$ & $0.44(0.17)^{*}$ & $0.12(0.15)$ & $0.52(0.16)$ & - & - & - & - \\
\hline \multicolumn{9}{|l|}{$\begin{array}{l}\text { Env lustice: Critical } \\
\text { Theory and } \\
\text { Economic Frame vs. } \\
\text { None }\end{array}$} \\
\hline $\begin{array}{l}\text { Critical Theory } \\
\text { frame }\end{array}$ & $-0.48(0.27)$ & $-1.03(0.51)^{*}$ & $-0.37(0.26)$ & $-0.94(0.52)^{*}$ & $-0.39(0.27)$ & $-1.0(0.50)^{* *}$ & - & - \\
\hline Economic frame & $0.23(0.21)$ & $0.33(0.31)$ & $0.21(0.20)$ & $0.3 \mathrm{I}(0.3 \mathrm{I})$ & $0.23(0.20)$ & $0.31(0.31)$ & - & - \\
\hline $\begin{array}{l}\text { SPOT Tracker vs. } \\
\text { Renewable Energy } \\
\text { Policies }\end{array}$ & & & - & - & & & & \\
\hline $\begin{array}{l}\text { Energy Efficiency } \\
\text { Policies }\end{array}$ & $0.61(0.24)^{* k}$ & $0.25(0.27)$ & - & - & $0.47(0.23)^{*}$ & $0.12(0.26)$ & $0.28(0.22)$ & $0.09(0.25)$ \\
\hline $\begin{array}{l}\text { Emissions, } \\
\text { Infrastructure, Grid, } \\
\text { and Rate Policies }\end{array}$ & $0.2(0.16)$ & $0.44(0.18)^{*}$ & - & - & $0.10(0.15)$ & $0.4(0.18)^{*}$ & $0.04(0.13)$ & $0.01(0.15)$ \\
\hline $\begin{array}{l}\text { Transportation } \\
\text { Policies }\end{array}$ & $\begin{array}{l}-0.73 \\
(0.18)^{* * * *}\end{array}$ & $-0.51(0.22)^{*}$ & - & - & $-0.62(0.17)^{* * *}$ & $-0.43(0.22)^{*}$ & $-0.52(0.17)^{* *}$ & $-0.43(0.21)^{*}$ \\
\hline $\begin{array}{l}\text { Financing and other } \\
\text { energy incentives }\end{array}$ & $-0.01(0.18)$ & $0.05(0.20)$ & - & - & $0.06(0.18)$ & $0.11(0.19)$ & $0.15(0.14)$ & $0.48(0.16)^{\text {*k* }}$ \\
\hline \multicolumn{9}{|l|}{$*_{p}<0.05$} \\
\hline \multicolumn{9}{|l|}{$* * p<0.01$} \\
\hline$* * * * \mathrm{p}<0.001$ & & & & & & & & \\
\hline
\end{tabular}

Top row indicates response variables. Numbers attached to 'Enacted' and 'Enacted and Bipartisan' signify the model. Estimates and standard errors are indicated for each variable.

Bills with certain characteristics pass more often in a bipartisan way than others. I analyze bill characteristics and political conditions that potentially impact likelihood of bill passage using eight generalized linear models that measure the effects of variables when controlling for all others included in the specific model. High level patterns are outlined below. One notable difference is the use of SPOT tracker categories rather than the specific bill classification distinctions in the bivariate analysis. Across the Enacted 1 and 2 models, bills pass significantly more often in purple and blue states than in red states. This trend is consistent for purple states in the Enacted and Bipartisan 1 and 2 models, however, bills that are both enacted and bipartisan pass less often in blue states. Bills that expand choice pass significantly more often compared to bills that restrict choice or impose new regulations. Regarding environmental 
justice, Critical theory bills pass significantly less often in a bipartisan way compared to bills that lack a justice component. In terms of the economic redistribution justice frame, the standard errors are nearly the same size as the estimates and show no significance when compared to the no environmental justice condition.

Somewhat surprisingly, I found that bills with financial components passed slightly less often than bills without them, which could possibly be explained by the variety of financial incentives that in some cases conflict with conservative values (Hess et al., 2016). However, bills with financial components pass in a bipartisan way slightly more often than those that exclude them. Exclusion of the expanded choice variable from the Enacted 3 and Enacted and Bipartisan 3 models shows covariance between the expanded choice and financial component variables. Bills in the last four models without the expanded choice component that have a financial component or are explicitly financing and energy incentive policies pass slightly more often and significantly more often in a bipartisan way. Lastly, transportation policies pass consistently less often across all models. When controlling for all other variables, energy efficiency policies significantly pass more often, and emissions, infrastructure, grid, and rate policies pass more often in a bipartisan way. All SPOT categories are compared to the Renewable Energy policies category for the sake of consistency with the bivariate analysis of vote share comparison to Renewable Energy Portfolio Standard changes. Financing and other energy incentive policies pass significantly more often without controlling for the other variables, which could be a result of covariance with the overarching financial component and expanded choice variables.

Partition decision trees generated by JMP for each SPOT category show certain combinations of policy components and political conditions that can predict passage to differing degrees. This insight can be used to better understand and craft decarbonization policies that may have a better chance of passing. It should be noted that this analysis does not take specific lobbying donations, or outside regulatory or political hurdles into account, yet aims to provide a clearer picture of what kinds of policies have passed in recent history at the subnational level from a framing standpoint. Table 9 shows the three best 'paths' to passage with the political status, financial, expanded choice, and environmental justice components as predictor variables based on leaf reports. Each path is written in order, with the first two listed predictor variables being the biggest contributors to the splitting criterion. For example, the best path to passage for Renewable Energy policies according to this model includes a bill that expands choice, does not have a justice component, includes a financial component, and is proposed within a blue state legislature. Examples of this kind of bill include: 1) California's AB1979, which expands the state's existing feed-in tariffs to include more small hydropower plants, and 2) Connecticut

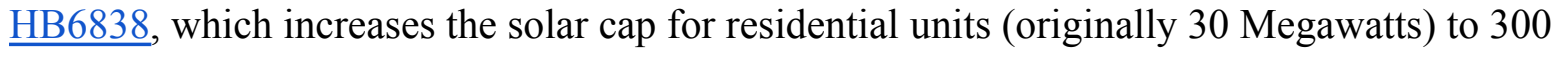
megawatts and creates solar home renewable energy credits. These new credits are owned by Connecticut's Green Bank and can be purchased and sold by electric distribution companies to help them meet mandated renewable energy goals and lower ratepayer costs (Mcready, 2015). 
Table 9: Decision Tree Results

\begin{tabular}{|c|c|c|c|}
\hline $\begin{array}{l}\text { SPOT Category Leaf } \\
\text { Report }\end{array}$ & Best path & Second best & Third best \\
\hline \multirow[t]{2}{*}{ Renewable Energy Policies } & $\begin{array}{l}\text { Expanded choice (yes), } \\
\text { No justice, Financial component } \\
\text { (yes), Political status (blue) }\end{array}$ & $\begin{array}{l}\text { Expanded choice (yes), Justice: } \\
\text { Economic frame, Political status } \\
\text { (purple) }\end{array}$ & $\begin{array}{l}\text { Expanded choice (yes), Justice: } \\
\text { economic frame, Political status } \\
\text { (purple) }\end{array}$ \\
\hline & Response prob $=95.6 \%$ & Response prob $=84.1 \%$ & Response prob $=84 \%$ \\
\hline \multirow[t]{3}{*}{$\begin{array}{l}\text { Emissions, Infrastructure, } \\
\text { Grid, and Rate Policies }\end{array}$} & $\begin{array}{l}\text { Expanded choice (yes, no effect), } \\
\text { No justice, Financial component }\end{array}$ & $\begin{array}{l}\text { Expanded choice (yes, no effect), No } \\
\text { justice, Financial component (no), }\end{array}$ & $\begin{array}{l}\text { Expanded choice (yes, no effect), } \\
\text { Justice: economic and critical theory }\end{array}$ \\
\hline & (yes), Political status (purple, red), & Political status (blue) & $\begin{array}{l}\text { frame, Political status (blue, purple), } \\
\text { Financial component (no) }\end{array}$ \\
\hline & Response prob $=93.8 \%$ & Response prob $=84.1 \%$ & Response prob $=72.3 \%$ \\
\hline \multirow[t]{2}{*}{ Energy Efficiency Policies } & $\begin{array}{l}\text { Expanded choice (yes), Financial } \\
\text { component (no) }\end{array}$ & $\begin{array}{l}\text { Expanded choice (yes), Financial } \\
\text { component (yes) }\end{array}$ & $\begin{array}{l}\text { Expanded choice (no or no effect), } \\
\text { Political status (blue, purple), }\end{array}$ \\
\hline & Response prob $=94 \%$ & Response prob $=76.4 \%$ & Response prob $=66.3 \%$ \\
\hline \multirow[t]{2}{*}{$\begin{array}{l}\text { Financing and other energy } \\
\text { incentive policies }\end{array}$} & $\begin{array}{l}\text { Expanded choice (yes) } \\
\text { Political status (blue), Justice: } \\
\text { economic frame }\end{array}$ & $\begin{array}{l}\text { Expanded choice (yes) } \\
\text { Political status (blue), Justice: No, or } \\
\text { critical theory frame }\end{array}$ & $\begin{array}{l}\text { Expanded choice (yes), } \\
\text { Political status (purple), }\end{array}$ \\
\hline & Response prob $=77.9 \%$ & Response prob $=73.3 \%$ & Response prob $=58.5 \%$ \\
\hline \multirow[t]{2}{*}{ Transportation Policies } & $\begin{array}{l}\text { Financial component (no), } \\
\text { Expanded choice (yes) }\end{array}$ & $\begin{array}{l}\text { Financial component (yes), Expanded } \\
\text { choice (yes), Political Status (blue) }\end{array}$ & $\begin{array}{l}\text { Financial component (no), Expanded } \\
\text { choice component (no effect, no) }\end{array}$ \\
\hline & Response prob $=65.6 \%$ & Response prob $=47.2 \%$ & Response prob $=40.8 \%$ \\
\hline
\end{tabular}

Table 9: Categorical variable splitting criterion is based on two main fit statistics: the $G^{\wedge} 2$ value and LogWorth. A 0.2 validation level was set to prevent overfitting. The validation datasets for each category were generally low $(<0.5)$ due to the categorical nature of the variables, with misclassification rates spanning from 0.17-0.4. This level of uncertainty requires caution in the interpretation of each tree. The Response Prob values indicate the estimate of a bill that follows the specific path passing. **See Appendix 4 for further results from these decision trees and statistical information.

\section{Discussion}

Addressing climate change requires rapid decarbonization of multiple sectors. If addressing climate change requires society-wide, multi-decadal effort, policy interventions seem unlikely to have the necessary scope or scale without significant bipartisan cooperation. State and local governments continue to be the primary driving forces of decarbonization policy in the United States (Center for New Energy Economy, 2020), which highlights the need to document areas of overlapping interests and cooperation. This analysis shows bill types that pass with high support levels through vote share and sponsorship measures, and the kinds of components that could make them disproportionately pass more often than others. 


\subsection{Key Takeaways}

I comprehensively review state-level decarbonization legislation with an eye towards opportunities for bipartisanship. Over half of the analyzed bills passed in Democrat-controlled state legislatures, in support of Hypothesis 1 (see Figure 4). Approximately one third of all bills passed in Republican controlled state legislatures, showing that there are opportunities for bipartisanship on specific issues. Of the 356 enacted bills from the first dataset, 183 passed with Democrat sponsors, 46 with Republicans, and 127 with members from both major parties. This analysis does not make claims about the effectiveness of legislation relating to ambition levels or concrete emissions reductions, but instead draws inspiration from recent bipartisan successes to propose considerations for policy makers and advocates when crafting future climate legislation.

Certain policy components and political conditions are associated with decarbonization bills that pass with bipartisan or Republican sponsors. Evidence from the bivariate analysis of vote share and bill sponsorship shows that mandatory standards, restrictions, and increased regulations (restricted choice) pass less often in a bipartisan way. They are also the kinds of laws that receive the least support when they do pass, in support of Hypothesis 2. Some of these specific examples include Renewable Portfolio Standards and emissions standards--both main components of subnational climate policy to date (Konisky, 2020). This pattern plays out in the following example: California's SB 350, which mandates a 50 percent RPS by 2030 in addition to requiring independent system operators (ISO) to conduct studies on the impact of a regional electricity market (Digital Journal, 2016). Conversely, policies that expand choice in addition to those that do not include an environmental justice component pass as a greater percentage of bipartisan or Republican sponsored bills (Figure G) and with more support from a vote share perspective, in support of Hypothesis 3 .

GLM models of passage and bipartisanship show that bills with expanded choice, without Critical theory justice, and in purple and blue states passed significantly more often in a bipartisan way (See Enacted and Bipartisan 1 in Table 8). One of the most surprising results is the financial component's slightly negative effect on passage in Enacted 1. This could be a result of the following: 1) Bills with financial components include a broader span of function with varying levels of Republican support than the SPOT Financial incentive category, and 2) the expanded choice component covaries with the financial component. Figures $\underline{6}$ and $\underline{7}$ show that PACE laws, solar incentives, and other financial incentives are popular with Republican legislators, while others including net metering, shared renewables, and transportation bills garner disproportionately more support from Democrats. Based on previous qualitative research in this area (Hess et al., 2016), tax credits can be a hit or miss for some Republican representatives in certain political contexts, who believe that no form of energy should be subsidized to promote the free market principle of competition. Expanded choice and political status are the variables with the most consistent significant effects on potential passage. Relatively few environmental justice related bills have been enacted since 2015 (69 including both distinctions). Figures $\underline{6}$ and $\underline{7}$ show that environmental justice related bills are generally 
unpopular, but especially so among Republican or bipartisan sponsors. This sample size is too small and the bill functions too varied to make generalizations across all environmental justice bills, though Hypothesis 4 is supported in that the analyzed critical-theory framed bills were passed less often in a bipartisan way. The effects of the economic redistribution frame relative to the no justice condition are mixed and ambiguous.

Decision tree modeling offers an innovative way of thinking about bill passage and failure according to key characteristics present within the text of the legislation, and in broader political contexts. For all but one SPOT category (Emissions, Infrastructure, Grid, and Rate Policies), expanded choice was one of the top two contributors to the overall fit. In half of the models (Financing and Other Energy Incentive Policies, Energy Efficiency Policies, and Renewable Energy Policies), expanded choice and political status are the top two contributors to the overall fit. Exactly one-third of the paths shown in Table 9 include some element of environmental justice and only one of the instances is present in a best path scenario (Financing and Other Energy Incentive Policies). This brings up the question of when and how to bundle policy framing components for higher chances of passing, although each state legislature presents differing challenges within a variety of contexts that should be taken into account. While prediction quality varies with policy category, with Transportation policies having the highest misclassification rates and lowest response probabilities, this is a tool that can be expanded on in other policy contexts, or expanded to aid in future decarbonization policy design (Table 9).

\subsection{Limitations}

The scope of this study is limited to passed and failed legislation, which introduces data gaps if there are states without bills in these categories on record. This was most often the case with failed bills, where no records existed for 16 states (See Appendix 1 for full list). Upon further research, these states, which included Texas and Georgia had hundreds of "introduced," bills. While this measure is helpful to identify which kinds of policies have enough support to be proposed, there is no distinction between passage or failure, and therefore is outside the scope of this analysis. Texas is a state with a history of stalling or weakening energy policies (Stokes, 2020), and part of that stalling has to do with keeping bills in their introductory stages.

Additionally, I acknowledge that there are possible ideas that exist in certain states, but are never proposed. I measure the success of bills contingent on proposal, but cannot speak to the political climates that may prevent ideas from being proposed. Lastly, this study cannot draw conclusions about the effectiveness of the analyzed bills relating to emissions reductions. Previous studies aim to quantify the emissions reductions achieved as a result of Renewable Portfolio Standards since they have been enacted in a majority of states and in place long enough for researchers to measure their effects on increasing renewable energy generation on a state-by-state basis (Wiser et al., 2016). This study, in contrast, includes more recent policies dating back to 2015 in addition to a variety of bills whose measured effects on emissions have not been studied yet. Despite the uncertainty surrounding many other kinds of decarbonization legislation, this 
introduces the question of how hard Democrats should try to work with Republicans on decarbonization policy, given the pressing challenges of climate change.

\subsection{Debate on Bipartisan Passage}

There is a current debate over whether Democrats should push climate legislation through when the opportunity arises, or if both parties should work together so that potential new legislation is not as easily overturned (ie. Trump rollbacks of over 100 Obama era environmental rules). As of December 2020, 254 cities, 10 states, and 12 tribes had committed to achieve the U.S. climate targets set in the Paris Climate Accord through signing the "We Are Still In" declaration (We are Still In, 2020). A 100\% renewable energy target or goal has been set by at least 170 cities and 11 counties (Sierra Club, 2020), and governors of 25 states have joined the U.S. Climate Alliance with a commitment to take actions that will advance the greenhouse gas (GHG) reduction goals of the Paris Agreement. A recent October 2020 poll from Yale Climate Change Communication also shows that $82 \%$ of Americans say $100 \%$ clean energy should be the U.S. energy goal (Yale Program on Climate Change Communication, 2020). One hypothesis that recent history may support is that broadly supported actions should be pursued (see Obamacare; Norman, 2017) even in the face of lobbying opposition, while those without that public support could potentially send Democrats a signal of caution (see November 2020 Midterms related to defunding law enforcement; Czachor, 2020).

In the climate context, legislation such as the Green New Deal (GND) includes far-reaching action in environmental and social justice along with financial incentives and new opportunities for renewable energy jobs, among other actions. Recent 2019 polls from Data for Progress reveal that 59 percent of U.S. voters support the GND, though this support is overwhelmingly Democratic (Data for Progress, 2019). The full passage of a GND type of policy may be less likely due to high levels of partisanship (Gardner, 2019) though a new report from Evergreen Action and polling from the Yale Program on Climate Change Communication shows that a federal Clean Electricity Standard is within reach in the coming years through possible budget reconciliation measures (Stokes and Ricketts, 2020). This is the kind of policy at the federal level that Democrats could feasibly push through legislatively, given that approximately 82 percent of U.S. voters think that $100 \%$ clean energy should be the U.S. energy goal (Yale Program on Climate Change Communication, 2020). Broad public support and more juridictions committing to renewable and clean energy targets can pave the path to more ambitious legislation, despite polarization regarding broad climate change statements.

\subsection{Policy Implications}

Each decarbonization policy comes with a story that includes stakeholders, both proponents and opponents, a regulatory climate, political conditions, and spheres of public interest or disinterest. Suggesting that a certain type of policy is best to propose would disregard 
the high levels of variability and complexity within the policymaking processes and external factors unique to each state government. However, this analysis shows that framing approaches that accentuate financial and expanded choice components of different bill types especially in purple states could be consequential to passage and broad bipartisan support.

\subsubsection{Mandates}

Legislation like the proposed GND is coined as a more ambitious policy and has proven to bear political framing consequences in recent years. However, a 2020 study on legislator opinions on renewable energy policies (Lee and Stecula, 2020) reveals that renewable energy mandates are more popular among subnational policymakers than the other choices provided in 2015 and 2017 surveys--carbon taxes, cap and trade, and emissions standards. The exact policies under this broad umbrella of mandates is not defined, though this analysis paints a clear picture of possible near future subnational bipartisanship that is not generally present at the national level. This analysis shows that REEPS and emissions standards are least likely to garner broad support, though certain framing approaches may be associated with high vote shares. The following table summarizes data from Figures $\underline{6}$ and $\underline{7}$ to better visualize patterns in mean vote share and financial, expanded choice, and environmental justice frames. Bills with all three frames, which also resemble the proposed GND at the federal level, have the lowest vote share behind bills with only environmental justice framing. Expanded choice only and expanded choice with a financial incentive have higher mean vote shares.

\section{Table 10: Framing components among Emissions Standards and RPS}

\begin{tabular}{lllrrr} 
Expanded Choice & Financial Incentive & Environmental Justice & Count & \multicolumn{2}{c|}{ Mean vote share } \\
None & None & None & 21 & 75.3 \\
Yes & Yes & Yes & 1 & 57.1 \\
Yes & None & None & 5 & 78.5 \\
Yes & Yes & None & 4 & 75.2 \\
None & None & Yes & 6 & 59.6
\end{tabular}

\subsubsection{Bright Spots in Red and Purple States}

Decarbonization initiatives pass more often in blue or purple states, but there are notable exceptions that should be recognized as seeds of future bipartisan action. Examples from press releases and grey literature provide poignant examples that are representative of the statistical patterns I found. Below, I provide some examples that qualitatively illustrate quantitative points. Notable exceptions in historically red states shows how the framing components play out. Georgia's solar market is a bright spot among states that are historically controlled by Republican trifectas. In 2015, the Solar Power Free-Market Financing Act lifted restrictions that prevented the solar market from growing. This new legislation allows businesses and individuals to participate in lease finance agreements, effectively scaling a significant financial barrier to solar adoption. In 2019, Georgia had the fifth largest solar market in the U.S. (SEIA, 2020) and is making strides in utility-scale solar through projects on farmland and agreements with 
agricultural leaders (Hsu and Kelly, 2019). When the law initially passed, Craig Briscoe, Executive Director of Georgians for Solar Freedom told Atlanta Progressive News:

"We advocate for solar through free market principles, so anything that introduces a new energy source, creating competition, the result is gonna be costs to be lowered... for the consumers to be the benefit of that occurrence. We advocate for anything that lowers consumer cost," The legislation "benefits the folks who hold those free market principles and the environmentalist contingency - it's very seldom when it's a win-win... This is good politics, good policy," he said (Cardinale, 2015).

Other bright spots in historically Republican controlled states include Arkansas' Solar Access Act of 2019 and South Carolina's Energy Freedom Act of 2019. Both include multiple functions to improve accessibility to solar in their respective states, passed with unprecedented legislative support (94.3\% and 98\% yes votes in the lower assemblies), and included a variety of stakeholder interests in the development stages. The Solar Access Act enables solar leasing and third party purchasing, triples the maximum solar size limit for businesses, and adopts a grandfathering provision to protect solar customers from future rate changes. Companies as big as Target and Walmart, local businesses, and local governments, and nonprofits like Audubon Arkansas, and the Arkansas Sierra Club supported negotiations and the final bill text. In a statement from one of the original sponsors,

"It's a great day for the Arkansas consumer. They will have more choices in the market now" (Moody, 2019).

The Solar Freedom Act in South Carolina includes an innovative change in the way utilities measure costs. This policy emphasizes an avoided cost calculation methodology, or "the cost avoided by not building another unit of utility-owned traditional power generation" (Robbins and Mango, 2019). This legislation also includes support for battery storage technology and investments in solar energy. By the time the bill made it to the governor's office, multiple stakeholders including regulatory staff, legislators, environmental organizations, utilities, and members of the business community had "logged countless hours crafting the language and building support on an unprecedented scale in the state" (Robbins and Mango, 2019). These policies highlight clear aspects of expanded consumer choice and financial incentives in context of free market principles.

\subsubsection{Broad Policy Impacts}

Some of the historic red states and voted Republican in the two most recent general elections do not have emissions standards and RPS policies (ie. Georgia), yet are leading the surge in renewable energy (solar and wind) nationwide. State policies are not driving this adoption in many red states; rather, strong market forces through federal tax credits and the abundance of solar and wind resources are likely to have spurred this trend (Gerdes, 2020). As of 2019, Kansas, Iowa, North Dakota, Oklahoma, Wyoming, Nebraska, and South Dakota, made 
the top ten according to the measure of wind and solar generation as a percentage of electricity consumption (Dutzik et al., 2019; see Appendix 5). As shown, Georgia's solar market has boomed in recent years. Although the total percentage of electricity generation in the state is fossil-fuel dominated, Georgia is ranked fifth in the nation regarding the Megawatts of solar installed (3,550.4 MW as of 2019), which is expected to grow by 1,923.88 MW over the next 5 years (SEIA, 2020). Standards and mandates play an important role in climate mitigation, though they are highly politicized in terms of framing and are disproportionately popular among Democrats. This illustrates that they may not always be the most effective policy types at the state level--especially in historically red states.

Renewable energy uptake is an economically sound transition through the lenses of economic development, sustained job creation, and a steady stream of revenue to benefit local governments (Gerdes, 2020). In the most recent general election, Biden voters made up 70 percent of the U.S. economy from 477 counties, while Trump voters made up just 29 percent of the economy from 2,497 counties (Muro et al., 2020). Economic activity is concentrated in blue counties, making renewable energy investments a key opportunity for red states and local governments going forward.

"Wind has been a godsend - it allows flexibility in budgeting by providing a constant source of revenues that you know will be there when you need them," Don Allred, Oldham County, KY judge (Gerdes, 2020).

When possible, state legislatures should enact and strengthen emissions standards and RPS in addition to other standards and programs pertaining to other decarbonization strategies. However, if this best path is not politically feasible, Democrats should worry less about mandates and standards and more on reducing regulatory barriers to widespread adoption and increasing incentive opportunities that compliment natural market forces.

In Republican controlled states or states that have fluctuating party control, policies with characteristics such as expanded choice and financial components that appeal to Republicans may be enacted more often than those that create new standards and restrictions, include a critical theory framing approach, and exclude financial incentives. On the other hand, partisanship may not be as big of a barrier to passing climate policies in blue states. Democratic governments in blue states will have to weigh the importance of bipartisanship against other potential objectives. For example, some might argue that Democrats should plow ahead with policies even if they are more ambitious than can pass in a bipartisan way, especially in cases where public opinion is behind them to a greater extent than Republicans in the state legislature (National Surveys on Energy and Environment, 2018), or if the goal of the bill is too important as some might argue in the case of bills with an environmental justice focus. A countervailing concern might be to the extent that affective polarization is high and is influencing popular opinions on various climate issues, Democrats may want to consider the possibility that enacting policies that are divisive and unpopular among voters of both parties, might poison the well for initiatives in other states or nationally. 


\subsubsection{Other Renewable Energy Legislation}

Variety is also a key part of this story. The most popular category for enacted bills is the "Other REEE," which is made up of bills that do not clearly fit into any of the classification categories. 40 percent (26) of these bills either establish a task force, a pilot program, a new authority, or commission a study. A combined 16 percent (10 bills) either provide guidance on future renewable energy investment planning or provide progress reports on emissions reductions goals (See Appendix 6). Other kinds of bills establish soil health initiatives for the purpose of reducing emissions from the agricultural sector, establish permanent environmental justice commissions, and make it harder for some states to pull out of the Regional Greenhouse Gas Initiative (RGGI). This shows that there is momentum behind legislation that explores new kinds of decarbonization and aims to hold states and utilities accountable to their goals. Despite this incremental approach to decarbonization that does not include mandatory standards, or direct financial incentives, a majority of these policies lay the groundwork for future policy. In red states like Tennessee, where one of the two notable bills since 2015 was the creation of an energy policy council (․․‥438), this approach can start introductory considerations of renewable energy, efficiency, and funding for related research that could inform more ambitious policies down the road.

\subsection{Future Research}

A number of bills include actions from multiple areas of renewable energy legislation in a single bill, which can in some cases be a more effective way to reform energy policy rather than enacting separate bills. One recent example is the national December 2020 COVID-19 relief bill that included multiple actions related to renewable energy incentives and pollution prevention, with the most significant action being the phaseout of hydrofluorocarbons (HFC) by 2035 that could result in $0.5 \mathrm{C}$ of avoided warming (Pilkington, 2020). In a recent December 2020 report from the Center for New Energy Economy, bills with multiple functions (coined as omnibus bills) increased nationally from 2016-2019 (Center for New Energy Economy, 2020). Examples in this analysis include: Vermont H40, which uses a mix of both a standard and on-bill financing for homeowners to improve energy efficiency. In addition to this trend, a recent study of 2,476 Americans by Bergquistt et al. evaluates the marginal impact of 40 climate, social, and economic policies on the overall support for climate action and reform. Interestingly, they show that a coalition building approach that couples certain economic and social policies including affordable housing, a \$15 minimum wage, or a job guarantee with climate policy makes climate action more popular especially among people of color (Bergquist et al., 2019). This is somewhat consistent with my economic framing approach to understanding environmental justice components in decarbonization legislation, although my results were not statistically significant. This raises the question of how voters might respond to different combinations of economic justice, critical theory framed bills, and other kinds of social justice initiatives. This is an important concept and launchpad for future research direction, where the success of different policy types when combined and alone can provide insight into the broader ideological framing 
of economic and social axes of liberal and conservative support (Novicoff, 2021). How and to what extent should other kinds of policies be bundled with climate?

Another important future research objective is analyzing the effectiveness of these policies after implementation. RPS is arguably the policy type that has been researched the most, though newer programs like PACE, shared renewable projects, and an assortment of financial incentives have not been heavily studied from a state or national level relating to estimated emissions reductions. Additionally, future research on this topic could gauge whether or not incremental policies like task forces, studies, and pilot programs are developed into long-lasting policies and programs.

\section{Conclusion}

Though bipartisanship faces documented challenges related to increasing tribalism, inherent ideological clashes, and anti-environment interest group influence, this analysis shows that there are opportunities to enact certain state-level decarbonization policies with both legislative and popular support. From a landscape lens, I found that a number of bills pass in Republican-controlled state legislatures, certain characteristics are associated with bipartisan sponsorship and vote share totals, and some pass more and less often than others. Bipartisan bills since 2015 take on different characteristics and are intended to serve a variety of functions, though they are disproportionately present in purple states, and are likely to include expanded choice or financial components without a focus on environmental justice, though notable exceptions exist. Bipartisanship is a key aspect of climate mitigation policy going forward, and can be better facilitated at the state-level through a focus on broadly popular initiatives and natural market forces that can provide expanded choices and opportunities that have never existed before. 


\section{References}

Advanced Energy Legislation Tracker. (2021). Center for New Energy Economy.

https://www.aeltracker.org/

Bar-Haim, Y., Ziv, T., Lamy, D., \& Hodes, R. M. (2006). Nature and nurture in own-race face processing. Psychological science, 17(2), 159-163.

https://doi.org/10.1111/j.1467-9280.2006.01679.x\

Beard, D. (2019, December 3). The 'Citizens United' decision and why it matters. Center for Public Integrity. https://publicintegrity.org/politics/the-citizens-united-decision-and-why-it-matters

Bergquist, P., Mildenberger, M., \& Stokes, L. C. (2020). Combining climate, economic, and social policy builds public support for climate action in the US. Environmental Research Letters, 15(5), 054019. https://doi.org/10.1088/1748-9326/ab81c1

Brulle, R. J. (2014). Institutionalizing delay: Foundation funding and the creation of U.S. climate change counter-movement organizations. Climatic Change, 122(4), 681-694. https://doi.org/10.1007/s10584-013-1018-7

Cardinale, M. C. (2015, January 15). Legislature May Approve Solar Panel Lease Financing, with Limits | Atlanta Progressive News. Atlanta Progressive News. http://atlantaprogressivenews.com/2015/01/15/legislature-may-approve-solar-panel-leas e-financing-with-limits/

Center for the New Energy Economy, Crew, S., Eisenbeis, E., Hoffer, T., Kelly, L., Oonk, D., Petrella, C., Plant, T., \& Tegen, S. (2020, December). SEVEN YEARS OF ADVANCED ENERGY ACTION 2013 - 2019 State Legislation in Review. https://www.aeltracker.org/graphics/uploads/2013-2019_State_Advanced_Energy_Action.pdf

Climate Leadership Council, Baker, J. A., Paulson, H. M., Feldstein, M., Shultz, G. P., Halstead, T., Stephenson, T., Mankiw, N. G., \& Walton, R. (2017, February). The Conservative Case for 


\section{Carbon Dividends.}

https://www.clcouncil.org/media/2017/03/The-Conservative-Case-for-Carbon-Dividends.pdf

Citizens' Climate Lobby. (2021, March 11). Climate Solutions Caucus | Citizens' Climate

Lobby. https://citizensclimatelobby.org/climate-solutions-caucus/

Czachor, E. (2020, December 6). Pollster Suggests Democrats Should Steer Clear of "Defund the Police" to Win in 2022. Newsweek. https://www.newsweek.com/pollster-suggests-democrats-should-steer-clear-defund-polic e-win-2022-1552669

Data For Progress. (2019, March 19). The Green New Deal Is Popular [Press release]. https://www.dataforprogress.org/the-green-new-deal-is-popular

Deutsch, A. (2019, August 29). Surge in young Republicans worried about the environment: survey. Reuters. https://www.reuters.com/article/us-environment-poll-republicans/surge-in-young-republicans-wor ried-about-the-environment-survey-idUSKCN1VJ17V

Digital Journal. (2016, January 14). ISO Public Meeting Begins Work to Transform Into Regional Grid - Press Release - Digital Journal [Press release]. http://www.digitaljournal.com/pr/2802953

Dunlap, R. E. \& McCright, A. M. (2011, August 18). Organized Climate Change Denial. Oxford Handbooks Online. https://www.oxfordhandbooks.com/view/10.1093/oxfordhb/9780199566600.001.0001/oxf ordhb-9780199566600-e-10

Dutzik, T., Friedman, J., \& Searson, E. (2020). Renewables on the Rise. Environment America. https://environmentamerica.org/feature/ame/renewables-rise-2020

Elliott, C. (2019, October 16). Both conservatives and liberals can agree on action on climate change. The Conversation. 
$\underline{\text { https://theconversation.com/both-conservatives-and-liberals-can-agree-on-action-on-clim }}$ ate-change- 124878

Ellsmoor, J. (2019, June 15). Renewable Energy Is Now The Cheapest Option - Even Without Subsidies. Forbes. https://www.forbes.com/sites/jamesellsmoor/2019/06/15/renewable-energy-is-now-the-c heapest-option-even-without-subsidies/?sh $=5 \mathrm{ff} 987885 \mathrm{a} 6 \mathrm{~b}$

Feinman, S., \& Entwisle, D. (1976). Children's Ability to Recognize Other Children's Faces. Child Development, 47(2), 506-510. doi:10.2307/1128809

FollowTheMoney.Org. (2020). Show Me - FollowTheMoney.org. https://www.followthemoney.org/show-me? $\mathrm{dt}=1 \& \mathrm{y}=2020,2019,2018,2017,2016,2015 \& \mathrm{f}-\mathrm{fc}=1,2,3$ $\& \mathrm{~d}-\mathrm{cci}=36,33 \#[\% 7 \mathrm{~B} 1 \% 7 \mathrm{Cgro}=\mathrm{y}, \mathrm{d}-\mathrm{et}$

Fund, D. (2020, August 14). 'Til Death Do Us Part(isanship). Democracy Fund Voter Study Group. https://www.voterstudygroup.org/publication/til-death-do-us-partisanship

Gardner, T. (2019, March 27). Republicans defeat Green New Deal in U.S. Senate vote Democrats call a stunt. Reuters. https://www.reuters.com/article/us-usa-climate-greennewdeal/republicans-defeat-green-new-dealin-u-s-senate-vote-democrats-call-a-stunt-idUSKCN1R71BZ

George, J. (2021, January 12). A Lesson on Critical Race Theory. American Bar Association. https://www.americanbar.org/groups/crsj/publications/human rights magazine home/civil-rights -reimagining-policing/a-lesson-on-critical-race-theory/

Gerdes, J. (2021, February 22). America's red states lead wind and solar power surge. Energy Monitor. https://energymonitor.ai/technology/renewables/americas-red-states-lead-wind-and-solar -power-surge

Haidt, J. (2012). The righteous mind: Why good people are divided by politics and religion. New 
York: Pantheon Books.

Helmuth, B., Gouhier, T. C., Scyphers, S., \& Mocarski, J. (2016). Trust, tribalism and tweets: Has political polarization made science a "wedge issue"? Climate Change Responses, 3(1), 3. https://doi.org/10.1186/s40665-016-0018-z

Hess, D. J., Coley, J. S., Mai, Q. D., \& Hilliard, L. R. (2015). Party differences and energy reform: Fiscal conservatism in the California legislature. Environmental Politics, 24(2), $228-248$.

Hess, D. J., Mai, Q. D., \& Brown, K. P. (2016). Red states, green laws: ideology and renewable energy legislation in the United States. Energy Research \& Social Science, 11, 19-28.

H.R.5460 - 100th Congress (1987-1988): Global Warming Prevention Act of 1988. (1988). Congress.Gov | Library of Congress. $\underline{\text { https://www.congress.gov/bill/100th-congress/house-bill/5460 }}$

Hsu, A., \& Kelly, M. L. (2019, June 24). How Georgia Became A Surprising Bright Spot In The U.S. Solar Industry. NPR. https://choice.npr.org/index.html?origin=https://www.npr.org/2019/06/24/733795962/how-georgi a-became-a-surprising-bright-spot-in-the-u-s-solar-industry

Iyengar, S., \& Westwood, S. (2014). Fear and Loathing Across Party Lines: New Evidence on Group Polarization. American Journal of Political Science, 59. https://doi.org/10.1111/ajps.12152 Iyengar, S., Sood, G., \& Lelkes, Y. (2012). Affect, Not Ideology: A Social Identity Perspective on Polarization. Public Opinion Quarterly, 76(3), 405-431. https://doi.org/10.1093/poq/nfs038

Iyengar, S., Lelkes, Y., Levendusky, M., Malhotra, N., \& Westwood, S. J. (2019). The Origins and Consequences of Affective Polarization in the United States. Annual Review of Political Science, 22(1), 129-146. https://doi.org/10.1146/annurev-polisci-051117-073034

Jæger, M. (2006). What Makes People Support Public Responsibility for Welfare Provision: Self-Interest or Political Ideology? A Longitudinal Approach. Acta Sociologica, 49(3), 
321-338. Retrieved March 20, 2021, from http://www.jstor.org/stable/20459943

JMP Help. (2021, March 18). JMP Statistical Discovery from SAS.

https://www.jmp.com/support/help/en/15.2/index.shtml\#page/jmp/partition-models.shtml

Karol, D. (2019). Red, Green, and Blue: The Partisan Divide on Environmental Issues

(Elements in American Politics). Cambridge University Press. https://doi.org/10.1017/9781108673266

Konisky, D. M. (2020). Handbook of U.S. Environmental Policy. Edward Elgar Pub. https://www.e-elgar.com/shop/usd/handbook-of-u-s-environmental-policy-9781788972833.html

Kulin, J., \& Johansson Sevä, I. (2019). The Role of Government in Protecting the Environment:

Quality of Government and the Translation of Normative Views about Government Responsibility into Spending Preferences. International Journal of Sociology, 49(2), 110-129. https://doi.org/10.1080/00207659.2019.1582964

Lee, N. R., \& Stecula, D. (2021). Subnational bipartisanship on climate change: Evidence from surveys of local and state policymakers. Climatic Change, 164(1), 20. https://doi.org/10.1007/s10584-021-02964-X

Leonard, C. (2019). Kochland: The Secret History of Koch Industries and Corporate Power in America. New York: Simon \& Schuster.

Mackie, D. M. (1986). Social identification effects in group polarization. Journal of Personality and Social Psychology, 50(4), 720-728. https://doi.org/10.1037/0022-3514.50.4.720

Mason, L. (2016). A Cross-Cutting Calm: How Social Sorting Drives Affective Polarization. Public Opinion Quarterly, 80(S1), 351-377.https://doi.org/10.1093/poq/nfw001

McCready, B. (2015, June 2). Branford Lawmaker Reed Leads Passage of Bill Concerning Renewable Energy. Branford, CT Patch. https://patch.com/connecticut/branford/branford-lawmaker-reed-leads-passage-bill-concerning-re newable-energy-0 
McGrath, B. M. (2020, November 4). Climate change: US formally withdraws from Paris agreement. BBC News. https://www.bbc.com/news/science-environment-54797743

Mekelburg, M. (2020, February 12). PolitiFact - What is an acceptable measure of bipartisanship? The Poynter Institute. https://www.politifact.com/factchecks/2020/feb/12/veronica-escobar/what-acceptable-measure-bi partisanship/

Meng, K. C., \& Rode, A. (2019). The social cost of lobbying over climate policy. Nature Climate Change, 9(6), 472-476. https://doi.org/10.1038/s41558-019-0489-6

Merkley, E., \& Stecula, D. (2020). Party Cues in the News: Democratic Elites, Republican Backlash, and the Dynamics of Climate Skepticism. British Journal of Political Science, 1-18. doi:10.1017/S0007123420000113

Mildenberger, M., \& Leiserowitz, A. (2017). Public opinion on climate change: Is there an economy-environment tradeoff? Environmental Politics, 26(5), 801-824. https://doi.org/10.1080/09644016.2017.1322275

Mildenberger, M., Marlon, J. R., Howe, P. D., \& Leiserowitz, A. (2017). The spatial distribution of Republican and Democratic climate opinions at state and local scales. Climatic Change, 145(3), 539-548. https://doi.org/10.1007/s10584-017-2103-0

Milman, O. (2020, February 26). Climate crisis more politically polarizing than abortion for US voters, study finds. The Guardian. https:/www.theguardian.com/us-news/2019/mav/21/climate-crisis-more-politically-polarizing-th $\underline{\text { an-abortion-for-us-voters-study-finds }}$

Mitchell, A., Gottfried, J., Kiley, J., \& Matsa, K. E. (2014, October 21). Political Polarization \& Media Habits. Pew Research Center's Journalism Project. https://www.journalism.org/2014/10/21/political-polarization-media-habits/ 
Moody, G. (2019, March 7). Major Step Forward, Solar Access Act Passed the Full Senate, Audubon Arkansas Urges House to do the Same. Audubon Arkansas. https://ar.audubon.org/press-release/major-step-forward-solar-access-act-passed-full-se $\underline{\text { nate-audubon-arkansas-urges-house-do }}$

Muro, M., Duke, E. B., Yang, Y., \& Maxim, R. (2021, February 26). Biden-voting counties equal 70\% of America's economy. What does this mean for the nation's political-economic divide? Brookings. https://www.brookings.edu/blog/the-avenue/2020/11/09/biden-voting-counties-equal-70-of-ameri cas-economy-what-does-this-mean-for-the-nations-political-economic-divide/

National Surveys on Energy and Environment. (2017, June). Strong Public Support for State-level Policies to Address Climate Change (No. 31). Issues in Energy and Environmental Policy. http://closup.umich.edu/issues-in-energy-and-environmental-policy/31/strong-public-sup port-for-state-level-policies-to-address-climate-change

National Surveys on Energy and Environment. (2018, October). Solar, Wind, and State Mandates: 10 Years of Renewable Energy in the NSEE (No. 39). Issues in Energy and Environmental Policy. http://closup.umich.edu/issues-in-energy-and-environmental-policy/39/solar-wind-and-state-mand ates-10-years-of-renewable-energy-in-the-nsee

Norman, B. J. (2021, January 14). Affordable Care Act Gains Majority Approval for First Time. Gallup.Com.https://news.gallup.com/pol1/207671/affordable-care-act-gains-majority-appr oval-first-time.aspx

Novicoff, M. (2021, February 20). Stop marketing race-blind policies as racial equity initiatives. Slow Boring. https://www.slowboring.com/p/race-blind-policies-racial-equity Nye, D. E. (1998). Consuming power: A social history of American energies. Cambridge, Mass: 
MIT Press.

Pettigrew, T. F. (1998). Intergroup contact theory. Annual Review of Psychology, 49, 65-85. https://doi.org/10.1146/annurev.psych.49.1.65

Pew Research Center - U.S. Politics \& Policy. (2014, June 12). Section 3: Political Polarization and Personal Life. https://www.pewresearch.org/politics/2014/06/12/section-3-political-polarization-and-per sonal-life/

Pew Research Center-U.S. Politics and Policy (2016). Feelings about partisans and the parties. Pew Research Center. https:/www.pewresearch.org/politics/2016/06/22/1-feelings-about-partisans-and-the-part ies/

Pew Research Center Science \& Society. (2018, May 14). Majorities See Government Efforts to Protect the Environment as Insufficient. https://www.pewresearch.org/science/2018/05/14/majorities-see-government-efforts-to-protect-th e-environment-as-insufficient/

Pilkington, E. (2021, January 7). Environmental groups hail Covid relief bill-but more needs to be done. The Guardian. https://www.theguardian.com/environment/2020/dec/24/environmental-groups-covid-relie $\underline{\text { f-bill-biden-trump }}$

Popovich, N., Albeck-Ripka, L., \& Pierre-Louis, K. (2021, January 21). The Trump Administration Rolled Back More Than 100 Environmental Rules. Here's the Full List. The New York Times Company. https://www.nytimes.com/interactive/2020/climate/trump-environment-rollbacks-list.html 
Robbins, S., \& Mango, M. (2019, July 24). Commentary: With Energy Freedom Act, South

Carolina takes steps toward resilience. Energy News Network.

https://energynews.us/2019/07/25/commentary-with-energy-freedom-act-south-carolina-t

akes-steps-toward-resilience/

Rockström, J., Gaffney, O., Rogelj, J., Meinshausen, M., Nakicenovic, N., \& Schellnhuber, H. J. (2017). A roadmap for rapid decarbonization. Science, 355(6331), 1269.

https://doi.org/10.1126/science.aah3443

SEIA. (2020). Georgia Solar: Data Current Through Q4 2020.

https://www.seia.org/state-solar-policy/georgia-solar

Sierra Club. (2020). 100\% Commitments in Cities, Counties, and States. Ready for 100.

Sovacool, B. K. (2014). What are we doing here? Analyzing fifteen years of energy scholarship and proposing a social science research agenda. Energy Research \& Social Science, 1, 1-29. https://doi.org/10.1016/j.erss.2014.02.003

Slothuus, R. (2010). When Can Political Parties Lead Public Opinion? Evidence from a Natural Experiment. Political Communication, 27(2), 158-177.

https://doi.org/10.1080/10584601003709381

Slothuus, R., \& De Vreese, C. (2010). Political Parties, Motivated Reasoning, and Issue Framing Effects. The Journal of Politics, 72(3), 630-645. doi:10.1017/s002238161000006x

SPOT | The State Policy Opportunity Tracker (SPOT) for Clean Energy. (2021). Center for New Energy

Economy. https://spotforcleanenergy.org/

Stokes, L. C. (2020). Short Circuiting Policy: Interest Groups and the Battle Over Clean Energy and Climate Policy in the American States (Studies in Postwar American Political Development). Oxford University Press. 
https://doi.org/10.1093/oso/9780190074258.001.0001

Stokes, L., \& Ricketts, S. (2021, February 4). How Biden and Congress could pass a popular climate change policy: Clean electricity. Vox.

https://www.vox.com/22265119/biden-climate-change-renewable-energy-clean-electricity -standard-congress

Stone, L. G. (2020, December 22). HB6 Is a Terrible Deal for Ohio. RMI. https://rmi.org/hb6-is-a-terrible-deal-for-ohio/

Sunstein, C. R. (2018). \#Republic: Divided Democracy in the Age of Social Media (Updated ed.). Princeton University Press. Afterword.

Tyson, A., \& Kennedy, B. (2020, June 23). Two-Thirds of Americans Think Government Should Do More on Climate. Pew Research Center Science \& Society. https://www.pewresearch.org/science/2020/06/23/two-thirds-of-americans-think-governm $\underline{\text { ent-should-do-more-on-climate/ }}$

Van Boven, L., Ehret, P. J., \& Sherman, D. K. (2018). Psychological Barriers to Bipartisan Public Support for Climate Policy. Perspectives on psychological science : a journal of the Association for Psychological Science, 13(4), 492-507. https://doi.org/10.1177/1745691617748966

We Are Still In. (2020). Who’s In. https://www.wearestillin.com/signatories

Wiser, R., G. Barbose, J. Heeter, T. Mai, L. Bird, M. Bolinger, A. Carpenter, G. Heath, D. Keyser, J. Macknick, A. Mills, and D. Millstein. (2016). A Retrospective Analysis of the Benefits and Impacts of U.S. Renewable Portfolio Standards. Lawrence Berkeley National Laboratory and National Renewable Energy Laboratory. NREL/TP-6A20-65005.

http://www.nrel.gov/docs/fy16osti/65005.pdf.

Worland, J. (2017, July 27). Climate Change Used to Be a Bipartisan Issue. Here's What Changed. Time. https://time.com/4874888/climate-change-politics-history/

Yale Program on Climate Change Communication. (2020, October 27). POLL: Voters Support 
Transition to 100\% Clean Economy [Press release].

https://climatenexus.org/wp-content/uploads/2015/09/Public-Gas-Poll-Press-Release.pdf

Appendix 1. State distinctions

\begin{tabular}{|c|c|c|}
\hline Blue States & Red States & Purple States \\
\hline $\begin{array}{l}\text { CA } \\
\text { CO } \\
\text { CT } \\
\text { DE } \\
\text { HI } \\
\text { IL } \\
\text { MD } \\
\text { MA } \\
\text { NJ } \\
\text { NY } \\
\text { OR } \\
\text { RI } \\
\text { VT } \\
\text { WA }\end{array}$ & \begin{tabular}{|l} 
AL \\
AK \\
AZ \\
AR \\
FL \\
GA \\
ID \\
IN \\
IA \\
KS \\
KY \\
LA \\
MI \\
MS \\
MO \\
MT \\
NE \\
NC \\
ND \\
OH \\
OK \\
PA \\
SC \\
SD \\
TN \\
TX \\
UT \\
WV \\
WI \\
WY
\end{tabular} & $\begin{array}{l}\text { ME } \\
\text { MN } \\
\text { NV } \\
\text { NH } \\
\text { NM } \\
\text { VA } \\
\\
\\
\\
\text { Red Highlights= No failed } \\
\text { bills to record }\end{array}$ \\
\hline
\end{tabular}


Appendix 2. Breakdown of Classifications by Financial, Expanded choice, and Environmental justice components.
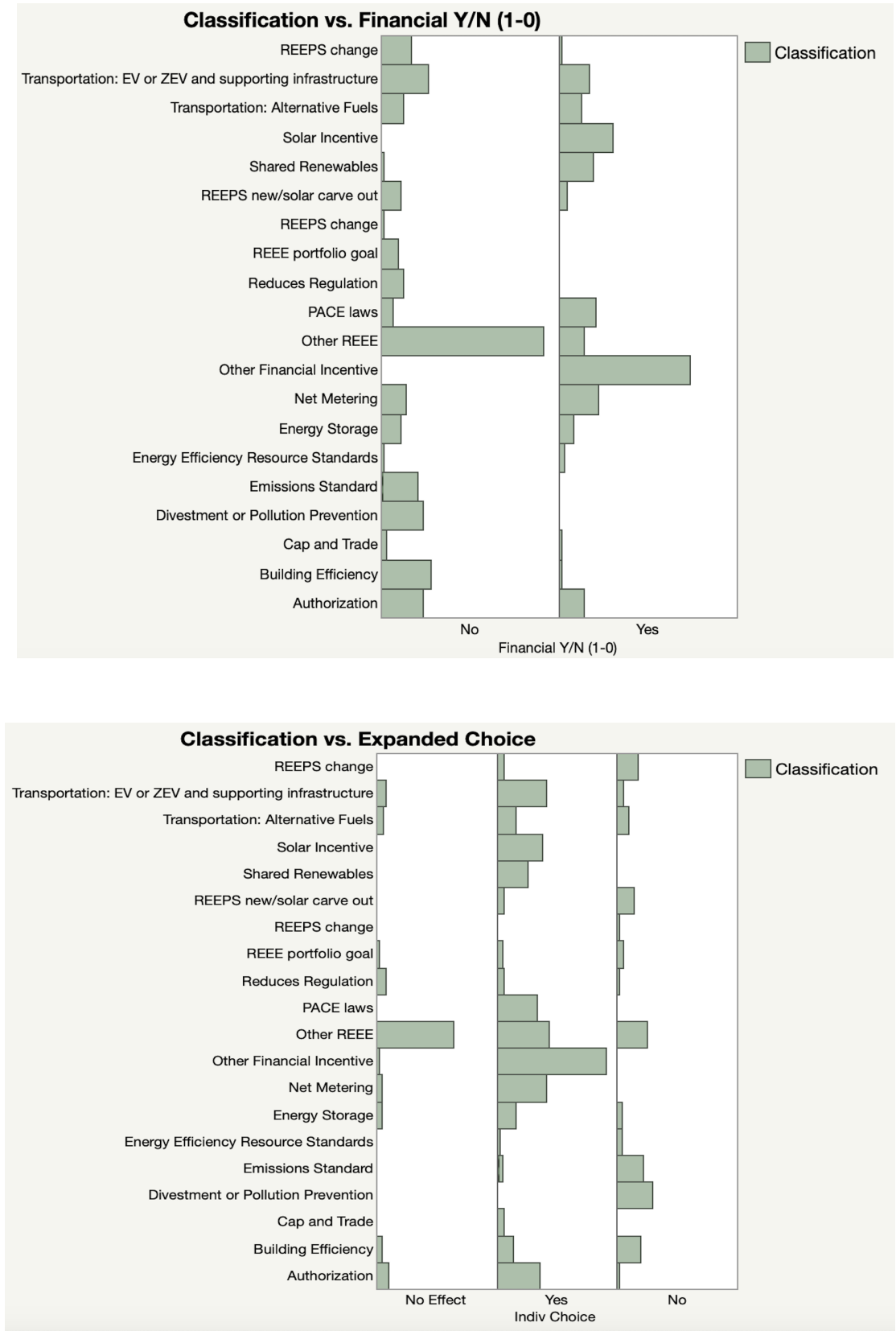


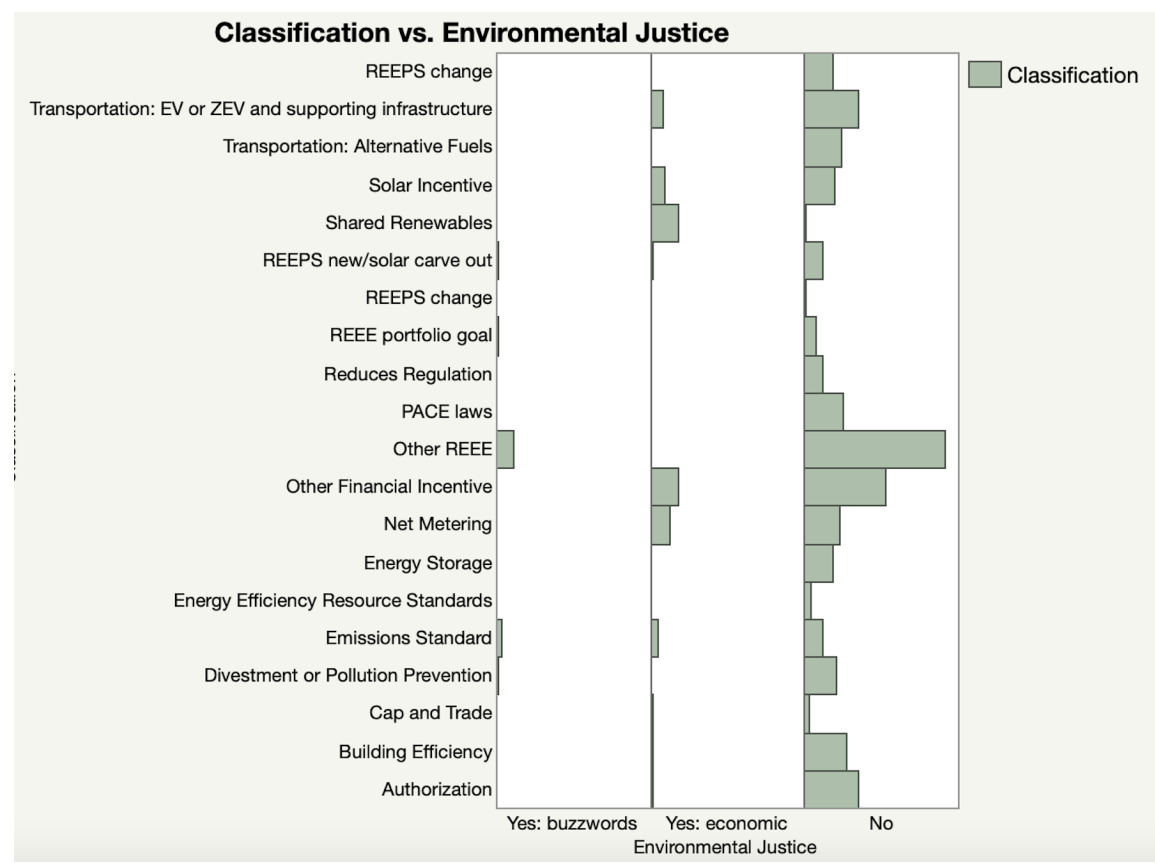

\section{Appendix 3: Bill Classification Rationale}

Green= added to Hess et al., 2016 categories

Black = Original Hess et al., 2016 categories

REEPS (two categories): new standards, changes in standards,.

- $\quad$ New standards are mandates such as $20 \%$ renewable energy by 2025 ;

- $\quad$ Changes in standards are included if they are non-trivial, such as an increase in the overall renewable portfolio standard from $10 \%$ to $25 \%$ within a designated time frame;

REEE portfolio goals are voluntary goals for utilities, and they are classified separately from REEE portfolio standards because we reasoned that if ideology played a role, there would be more support for goals than for standards.

- $\quad$ Renewable natural gas

\section{Building efficiency:}

- $\quad$ Establishes energy efficiency standards for state and/or municipal buildings other than schools. Residences and businesses are not included.

- $\quad$ Provides support for energy efficiency measures in schools, and in commercial and residential buildings, and includes miscellaneous measures to support government building efficiency (includes some tax credits for building efficiency measures)

- $\quad$ Includes providing information about energy efficient options to homeowners and incentivizing builders.

\section{Net Metering}

- Establishes or alters net metering provisions, usually in a significant way such as by increasing the capacity or subscriber limit or by expanding net metering to new categories of utilities and customers.

- $\quad$ Feed-in tariffs and incremental inclusions of new types of energy.

PACE laws: first-time authorizations of residential and/or commercial buildings but not for minor changes in PACE financing or for implementation clarification.

\section{Solar incentives:}

- $\quad$ Tax credit for solar energy generation, or limit on permitting fees, for homeowners and businesses that buy photovoltaic systems (can include solar and wind together).

- $\quad$ Providing cost recovery of installations

\section{Other financial incentives:}


- $\quad$ Financial incentives other than solar tax credits and fee reductions, including tax credits for geothermal and other renewable energy; Grant and loan programs for REEE, Modifications in the financing of PACE programs, Business incentives, On-bill financing programs.

- $\quad$ Incentives to help homeowners switch from wood burning stoves to more efficient heating options (CA)

- $\quad$ Demand response program incentives

- $\quad$ Self generation incentives and rebate programs

- $\quad$ Microgrid commercialization and loans Incentives for coal transition communities (CO)

- $\quad$ Funding new clean energy jobs (MD)

- $\quad$ Tax credit for demand side mgmt tariff

- $\quad$ Market based programs (cap and trade)

Reduce regulation: facilitates REEE by reducing regulatory hurdles such as for siting and permitting, streamlining permit process (includes expediting permitting process for EV charging infrastructure, includes allowing nuclear to compete with other zero carbon energy sources $(\mathrm{CT})$

\section{Authorization:}

- $\quad$ Allows a government entity to undertake an action in support of REEE, usually a local government that is restricted by a state-government regulation.

- $\quad$ Authorizing financial assistance for a new form of renewable energy not currently allowed (the procurement of energy derived from anaerobic digestion, offshore wind, new hydropower project in AK,)

- $\quad$ Authorizing energy storage technology

- $\quad$ Ocean renewable energy siting

\section{REEE other:}

- $\quad$ Requires a study, regulates REEE, establishes a commission, defines licensing requirements, modifies greenhouse gas rules,

- Starts a pilot project,

- $\quad$ Replenishing or starting a greenhouse gas or clean air fund

- $\quad$ Required GHG intensity reporting,

- Local distributed energy program (CA),

- $\quad$ Extend cap and trade program (CA),

- $\quad$ Global Warming Potential for products must be labeled (CA),

- Electrolytic hydrogen specified as energy storage technology (CA),

- Greenhouse gas fiscal notes on legislative measures (CO),

- $\quad$ Collect long term climate change data (CO),

- $\quad$ Create a homeowner-generated useful thermal energy program (CT),

- Omnibus bill ,

- $\quad$ Prohibiting petroleum infrastructure permitting (GA),

- $\quad$ Making it harder to withdraw from RGGI (MD),

- Grid modernization roadmap (NM),

Dirty Energy divestment

- Includes Prohibiting authorization for certain offshore oil and gas production

- ban offshore development and exploration oil and gas

- $\quad$ Creates a fine for coll rolling (DE),

- $\quad$ Retiring a coal plant

Transportation

- $\quad$ Alternative fuels: includes incentives and standards for alternatively fueled vehicles, emissions reduction standards

- $\quad$ EV or ZEV and supporting infrastructure: includes building out charging infrastructure, rebates for clean vehicles and/or components, EV fleet standards, ZEV standards, preparing utilities to provide infrastructure and participate in the EV marketplace.

\section{Environmental Justice (2 categories)}

- $\quad$ Critical theory buzzwords

- $\quad$ Economic frame: includes community solar and shared renewable energy projects

\section{Energy Storage}

- Development of energy storage funding, programs, and incentives. 
Appendix 4: Decision Trees

Node splitting criterion is based on the LogWorth and $\mathrm{G}^{\wedge} 2$ statistics. The optimal split maximizes the LogWorth. This is found in the Candidate reports for each node and is calculated like this:

$-\log 10(p$-value $)$

Likelihood ratio chi-square for the best split. Splitting on the predictor with the largest $\mathrm{G}^{\wedge} 2$ maximizes the reduction in the model $\mathrm{G}^{\wedge} 2$.

A candidate $G 2$ that has been chosen is:

$G 2$ test $=G 2$ parent $-(G 2$ left $+G 2$ right $)$. 


\section{Renewable Energy Policies}

\begin{tabular}{l|r|r|r|r|}
\hline \multicolumn{2}{l}{ Column Contributions } \\
Term & $\begin{array}{l}\text { Number } \\
\text { of Splits }\end{array}$ & G^2 & & \\
Portion \\
Expanded CHoice
\end{tabular}

\section{Leaf Report}

\section{Response Prob}

Leaf Label

Expanded CHoice(Yes)^\&Environmental Justice(No)\&Political Status(Blue)\&Financial Component(Yes)

Expanded CHoice(Yes)^\&Environmental Justice(No)\&Political Status(Blue)\&Financial Component(No)

Expanded CHoice(Yes)^\&Environmental Justice(No)\&Political Status(Purple)

Expanded CHoice(Yes)^\&Environmental Justice(Yes: economic)\&Political Status(Purple)

Expanded CHoice(Yes)^\&Environmental Justice(Yes: economic)\&Political Status(Blue)

Expanded CHoice(Yes)\&Political Status(Red)

^\&Environmental Justice(Yes: Critical theory, No)^\&Political Status(Blue)\&Expanded CHoice(No)

$\wedge \&$ Environmental Justice(Yes: Critical theory, No)^\&Political Status(Blue)\&Expanded CHoice(No Effect)

Expanded CHoice(No Effect, No)\&Environmental Justice(Yes: Critical theory, No)^\&Political Status(Purple

Expanded CHoice(No Effect, No)\&Environmental Justice(Yes: Critical theory, No)\&Political Status(Red)

Expanded CHoice(No Effect, No)\&Environmental Justice(Yes: economic)

Response Counts

Leaf Label

Expanded CHoice(Yes)^\&Environmental Justice(No)\&Political Status(Blue)\&Financial Component(Yes)

Expanded CHoice(Yes)^\&Environmental Justice(No)\&Political Status(Blue)\&Financial Component(No)

Expanded CHoice(Yes)^\&Environmental Justice(No)\&Political Status(Purple)

Expanded CHoice(Yes)^\&Environmental Justice(Yes: economic)\&Political Status(Purple)

Expanded CHoice(Yes)^\&Environmental Justice(Yes: economic)\&Political Status(Blue)

Expanded CHoice(Yes)\&Political Status(Red)

^\&Environmental Justice(Yes: Critical theory, No)^\&Political Status(Blue)\&Expanded CHoice(No)

$\wedge$ ^Environmental Justice(Yes: Critical theory, No)^\&Political Status(Blue)\&Expanded CHoice(No Effect)

Expanded CHoice(No Effect, No)\&Environmental Justice(Yes: Critical theory, No)^\&Political Status(Purple)

Expanded CHoice(No Effect, No)\&Environmental Justice(Yes: Critical theory, No)\&Political Status(Red)

Expanded CHoice(No Effect, No)\&Environmental Justice(Yes: economic)

\section{Fit Details}

\section{Measure}

Entropy RSquare

Generalized RSquare

Mean -Log $p$

RASE

Mean Abs Dev

Misclassification Rate

$\mathrm{N}$

\section{Training Validation Definition}

$0.2431 \quad 0.2003$ 1-Loglike(model)/Loglike(0)

$0.3811 \quad 0.3232\left(1-(L(0) / L(\text { model }))^{\wedge}(2 / n)\right) /\left(1-L(0)^{\wedge}(2 / n)\right)$

$0.5234 \quad 0.5540 \sum-\log (\rho[j]) / n$

$0.4190 \quad 0.4339 \sqrt{ } \sum(y[j]-\rho[j])^{2} / n$

$0.3614 \quad 0.3884 \sum \mid y[i]-\rho[j] / n$

$0.3030 \sum(\rho[j] \neq \rho M a x) / n$

$33 \mathrm{n}$

\section{Confusion Matrix}

\begin{tabular}{|c|c|c|}
\hline \multicolumn{3}{|c|}{ Training } \\
\hline Actual & $\begin{array}{r}\text { Pred } \\
\text { Co }\end{array}$ & \\
\hline Enacted & 0 & 1 \\
\hline 0 & 56 & 9 \\
\hline 1 & 28 & 45 \\
\hline
\end{tabular}

1

0.0453

0.1703

0.1595

0.1603

0.3388

0.6751

0.5008

0.6263

0.6142

0.7944

0.9150

\section{Crossvalidation \\ k-fold -2LogLike RSquare \\ 5 Folded $170.304216 \quad 0.1076$ \\ Overall $142.759342 \quad 0.2431$}

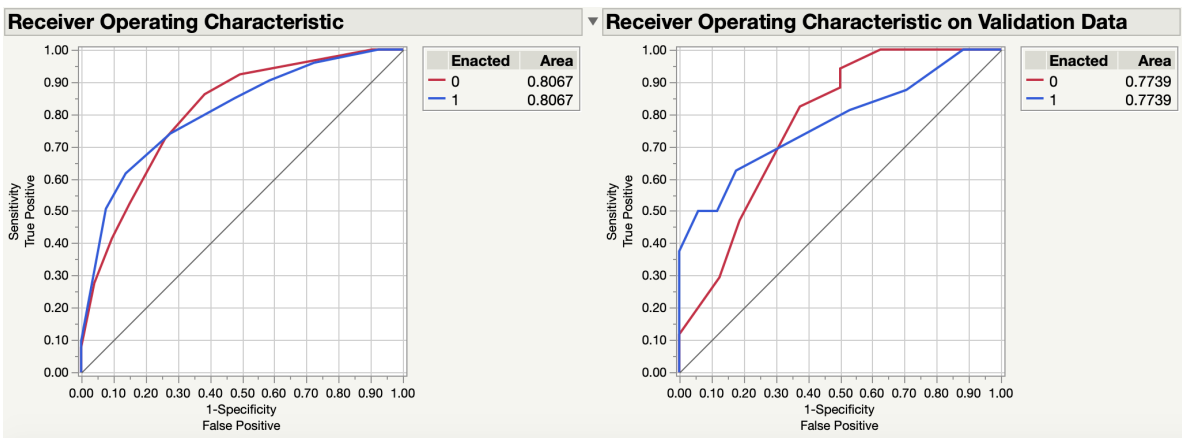




\section{Energy Efficiency Policies}

\begin{tabular}{|c|c|c|}
\hline \multicolumn{3}{|c|}{ Column Contributions } \\
\hline Term & $\begin{array}{l}\text { Number } \\
\text { of Splits }\end{array}$ & Portion \\
\hline Expanded CHoice & 15.52088982 & 0.4955 \\
\hline Political Status & 13.67253105 & 0.3296 \\
\hline Financial Component & 11.94854533 & 0.1749 \\
\hline Environmental Justice & $0 \quad 0$ & 0.0000 \\
\hline
\end{tabular}

\section{Leaf Report}

\section{Response Prob}

\section{Leaf Label}

Expanded CHoice(Yes)\&Financial Component(No)

Expanded CHoice(Yes)\&Financial Component(Yes)

Expanded CHoice(No, No Effect)\&Political Status(Purple, Blue)

Expanded CHoice(No, No Effect)\&Political Status(Red)

Response Counts

\section{Leaf Label}

Expanded CHoice(Yes)\&Financial Component(No)

Expanded CHoice(Yes)\&Financial Component(Yes)

Expanded CHoice(No, No Effect)\&Political Status(Purple, Blue)

Expanded CHoice(No, No Effect)\&Political Status(Red)
Portion

0.3296

0.0000

\section{Fit Details}

\begin{tabular}{|c|c|c|}
\hline Measure & Training & Validation Definition \\
\hline Entropy RSquare & 0.1879 & 0.3225 1-Loglike(model)/Loglike(0) \\
\hline Generalized RSquare & 0.3005 & $0.4803\left(1-(\mathrm{L}(0) / L(\text { model }))^{\wedge}(2 / n)\right) /\left(1-\mathrm{L}(0)^{\wedge}(2 / \mathrm{n})\right)$ \\
\hline Mean $-\log p$ & 0.5397 & $0.4684 \sum-\log (\rho[j]) / n$ \\
\hline RASE & 0.4277 & $0.3866 \sqrt{ } \sum(y[j]-\rho[j])^{2} / n$ \\
\hline Mean Abs Dev & 0.3764 & $0.3472 \sum|y[i]-\rho[j]| / n$ \\
\hline Misclassification Rate & 0.2619 & $0.1765 \sum(\rho[j] \neq \rho M a x) / n$ \\
\hline $\mathrm{N}$ & 42 & 17 \\
\hline
\end{tabular}

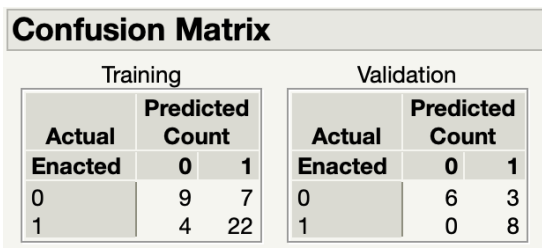

\section{Crossvalidation \\ k-fold $\quad$-2LogLike RSquare \\ 5 Folded $55.350739 \quad 0.0084$ \\ Overall $44.6784226 \quad 0.1879$}

Receiver Operating Characteristic

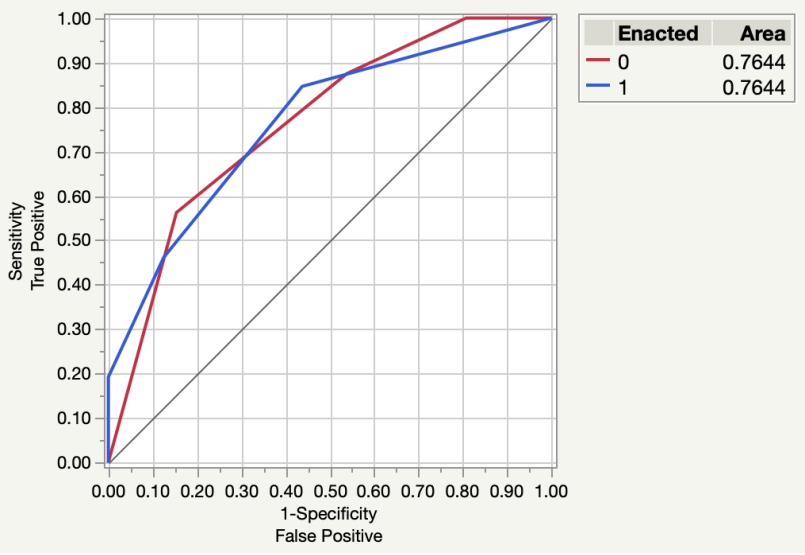

Receiver Operating Characteristic on Validation Data

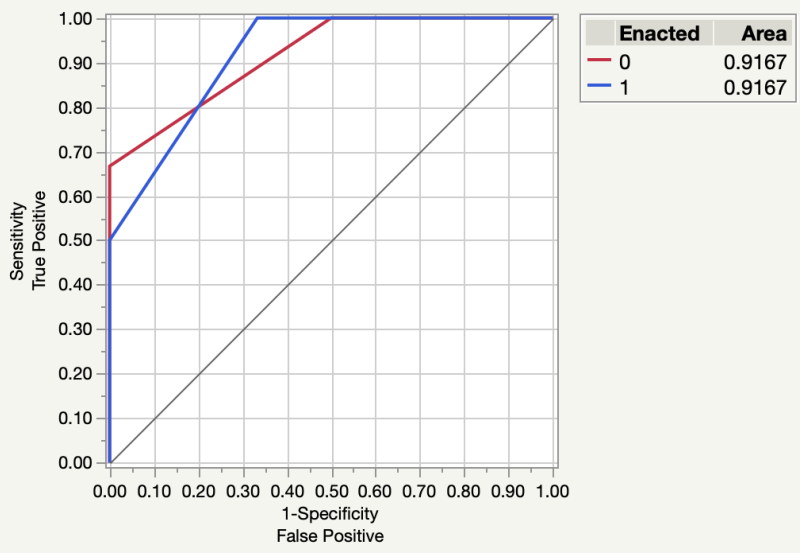




\section{Financing and other Energy Incentives}

\begin{tabular}{|c|c|c|}
\hline Term & $\begin{array}{l}\text { Number } \\
\text { of Splits }\end{array}$ & Portion \\
\hline Political Status & 29.22880667 & 0.5032 \\
\hline Expanded CHoice & 28.93732245 & 0.4873 \\
\hline Environmental Justice & $\left.\begin{array}{ll}1 & 0.1747317\end{array}\right]$ & 0.0095 \\
\hline Financial Component & $\begin{array}{ll}0 & 0\end{array}$ & 0.0000 \\
\hline
\end{tabular}

\section{Leaf Report}

\section{Response Prob}

\section{Leaf Label}

Expanded CHoice(Yes)\&Political Status(Blue)\&Environmental Justice(Yes: economic)

0

0.2206

Expanded CHoice(Yes)\&Political Status(Blue)\&Environmental Justice(No, Yes: Critical theory)

Expanded CHoice(Yes)^\&Political Status(Purple)

Expanded $\mathrm{CHoice}(\mathrm{Yes})^{\wedge} \&$ Political Status(Red)

$\wedge \&$ Expanded CHoice(No Effect)

$\wedge$ \&Expanded $\mathrm{CHoice}(\mathrm{No})$

Response Counts

\section{Leaf Label}

Expanded CHoice(Yes)\&Political Status(Blue)\&Environmental Justice(Yes: economic)

Expanded CHoice(Yes)\&Political Status(Blue)\&Environmental Justice(No, Yes: Critical theory)

Expanded CHoice(Yes)^\&Political Status(Purple)

Expanded CHoice(Yes)^\&Political Status(Red)

$\wedge$ \&Expanded CHoice(No Effect)

$\wedge \&$ Expanded CHoice(No)

\begin{tabular}{|c|c|c|}
\hline \multicolumn{3}{|l|}{ Fit Details } \\
\hline Measure & Training & Validation Definition \\
\hline Entropy RSquare & 0.0931 & 0.0513 1-Loglike(model)/Loglike(0) \\
\hline Generalized RSquare & 0.1609 & $0.0915\left(1-(\mathrm{L}(0) / \mathrm{L}(\text { model }))^{\wedge}(2 / \mathrm{n})\right) /\left(1-\mathrm{L}(0)^{\wedge}(2 / \mathrm{n})\right)$ \\
\hline Mean - Log $p$ & 0.6242 & $0.6571 \sum-\log (\rho[j]) / \mathrm{n}$ \\
\hline RASE & 0.4659 & $0.4823 \sqrt{ } \sum(y[i]-\rho[i])^{2 / n}$ \\
\hline Mean Abs Dev & 0.4375 & $0.4535 \sum \mid y[j]-\rho[j] / / n$ \\
\hline Misclassification Rate & 0.3451 & $0.3548 \sum(\rho[j] \neq \rho M a x) / n$ \\
\hline $\mathrm{N}$ & 142 & 31 \\
\hline
\end{tabular}

\begin{tabular}{|c|c|c|c|c|c|}
\hline \multicolumn{6}{|c|}{ Confusion Matrix } \\
\hline \multicolumn{3}{|c|}{ Training } & \multicolumn{3}{|c|}{ Validation } \\
\hline Actual & \multicolumn{2}{|c|}{$\begin{array}{l}\text { Predicted } \\
\text { Count }\end{array}$} & Actual & \multicolumn{2}{|c|}{$\begin{array}{l}\text { Predicted } \\
\text { Count }\end{array}$} \\
\hline Enacted & 0 & 1 & Enacted & 0 & 1 \\
\hline 0 & 40 & 24 & 0 & 8 & 7 \\
\hline 1 & 25 & 53 & 1 & 4 & 12 \\
\hline
\end{tabular}

\section{Crossvalidation

\begin{tabular}{rrrr}
\hline k-fold & -2LogLike & RSquare \\
3 Folded & 194.26975 & 0.0061 \\
Overall & 177.130412 & 0.0931
\end{tabular}

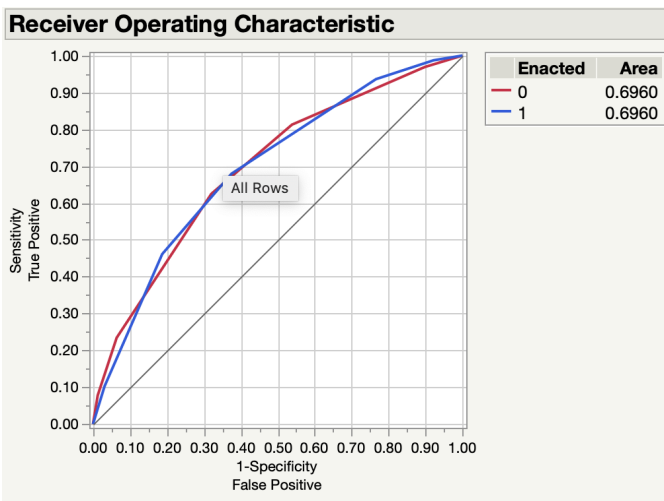

- Receiver Operating Characteristic on Validation Data

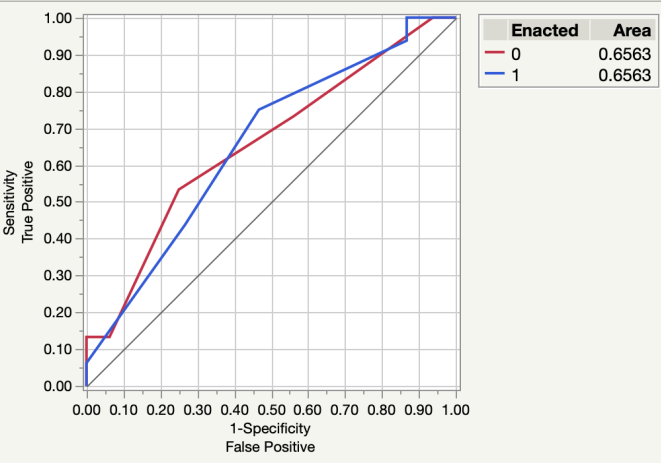




\section{Emissions, Infrastructure, Grid, and Rate Policies}

\begin{tabular}{|c|c|c|c|}
\hline \multicolumn{4}{|c|}{ Column Contributions } \\
\hline Term & $\begin{array}{l}\text { Number } \\
\text { of Splits }\end{array}$ & G^2 & Portion \\
\hline Political Status & & 15.7333437 & 0.4130 \\
\hline Financial Component & 3 & 10.9235512 & 0.2868 \\
\hline Expanded $\mathrm{CHoice}$ & 2 & 6.38358039 & 0.1676 \\
\hline Environmental Justice & 1 & 5.0533068 & 0.1327 \\
\hline
\end{tabular}

\section{Leaf Report}

Response Prob

Leaf Label

Expanded CHoice(Yes, No Effect)\&Environmental Justice(No)\&Financial Component(Yes)\&Political Status(Purple, Red)

Expanded CHoice(Yes, No Effect)\&Environmental Justice(No)\&Financial Component(Yes)\&Political Status(Blue)

$\wedge$ \&Environmental Justice(No)\&Financial Component(No)\&Expanded CHoice(Yes)

^\&Environmental Justice(No)\&Financial Component(No)\&Expanded CHoice(No Effect)

Expanded CHoice(Yes, No Effect)\&Environmental Justice(Yes: economic, Yes: Critical theory)\&Political Status(Purple, Blue)\&Financial Component(No)

Expanded CHoice(Yes, No Effect)\&Environmental Justice(Yes: economic, Yes: Critical theory)\&Political Status(Purple, Blue)\&Financial Component(Yes)

Expanded CHoice(Yes, No Effect)\&Environmental Justice(Yes: economic, Yes: Critical theory)\&Political Status(Red)

Expanded CHoice(No)\&Political Status(Purple, Blue)\&Financial Component(No)

Expanded CHoice(No)\&Political Status(Purple, Blue)\&Financial Component(Yes)

Expanded CHoice(No)\&Political Status(Red)

Response Counts

Expanded CHoice(Yes, No Effect)\&Environmental Justice(No)\&Financial Component(Yes)\&Political Status(Purple, Red)

Expanded CHoice(Yes, No Effect)\&Environmental Justice(No)\&Financial Component(Yes)\&Political Status(Blue)

^\&Environmental Justice(No)\&Financial Component(No)\&Expanded CHoice(Yes)

$\wedge$ \&Environmental Justice(No)\&Financial Component(No)\&Expanded CHoice(No Effect)

Expanded CHoice(Yes, No Effect)\&Environmental Justice(Yes: economic, Yes: Critical theory)\&Political Status(Purple, Blue)\&Financial Component(No)

Expanded CHoice(Yes, No Effect)\&Environmental Justice(Yes: economic, Yes: Critical theory)\&Political Status(Purple, Blue)\&Financial Component(Yes)

Expanded CHoice(Yes, No Effect)\&Environmental Justice(Yes: economic, Yes: Critical theory)\&Political Status(Red)

Expanded CHoice(No)\&Political Status(Purple, Blue)\&Financial Component(No)

Expanded CHoice(No)\&Political Status(Purple, Blue)\&Financial Component(Yes)

Expanded CHoice(No)\&Political Status(Red)

\section{Fit Details}

\begin{tabular}{|c|c|c|}
\hline Measure & Training & Validation Definition \\
\hline Entropy RSquare & 0.1362 & 0.0649 1-Loglike(model)/Loglike(0) \\
\hline Generalized RSquare & 0.2294 & $0.1137\left(1-(\mathrm{L}(0) / \mathrm{L}(\text { model }))^{\wedge}(2 / \mathrm{n})\right) /\left(1-\mathrm{L}(0)^{\wedge}(2 / \mathrm{n})\right)$ \\
\hline Mean -Log p & 0.5987 & $0.6364 \sum-\log (\rho[j]) / n$ \\
\hline RASE & 0.4572 & $0.4687 \sqrt{ } \sum(y[j]-\rho[j])^{2} / n$ \\
\hline Mean Abs Dev & 0.4251 & $0.4305 \sum|y[j]-\rho[j]| / n$ \\
\hline Misclassification Rate & 0.3646 & $0.3684 \sum(\rho[j] \neq \rho M a x) / n$ \\
\hline $\mathrm{N}$ & 192 & 38 \\
\hline
\end{tabular}

\begin{tabular}{|c|c|c|c|c|}
\hline \multicolumn{5}{|c|}{ Confusion Matrix } \\
\hline \multicolumn{3}{|c|}{ Training } & \multicolumn{2}{|c|}{ Validation } \\
\hline Actual & $\begin{array}{r}\text { Pred } \\
\text { Co }\end{array}$ & $\begin{array}{l}\text { ted } \\
\text { nt }\end{array}$ & Actual & $\begin{array}{c}\text { Predicted } \\
\text { Count }\end{array}$ \\
\hline Enacted & 0 & 1 & Enacted & 0 \\
\hline 0 & 68 & 27 & 0 & 9 \\
\hline 1 & 43 & 54 & 1 & $7 \quad 15$ \\
\hline
\end{tabular}

\section{Crossvalidation

\begin{tabular}{r|r|r}
\hline k-fold & -2LogLike & RSquare \\
5 Folded & 263.418892 & 0.0103 \\
Overall & 228.053901 & 0.1362
\end{tabular}

Receiver Operating Characteristic

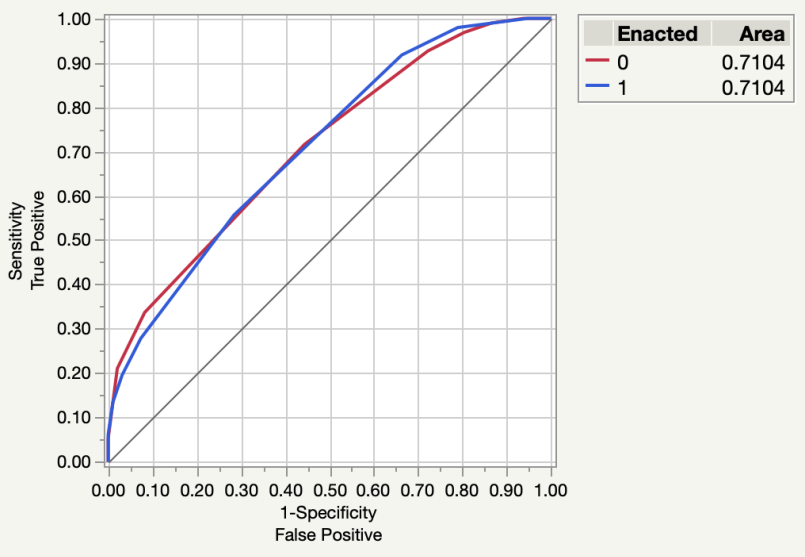

Veceiver Operating Characteristic on Validation Data

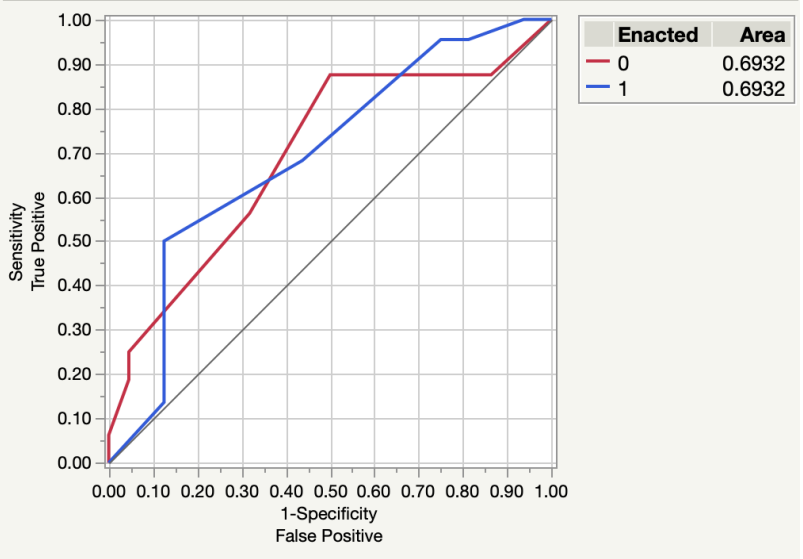




\section{Transportation Policies}

\begin{tabular}{|c|c|c|}
\hline \multicolumn{3}{|c|}{ Column Contributions } \\
\hline Term & $\begin{array}{l}\text { Number } \\
\text { of Splits }\end{array}$ & Portion \\
\hline Expanded Choice & 27.73159094 & 0.4626 \\
\hline Financial Component & 15.32383881 & 0.3185 \\
\hline Political Status & 13.6582071 & 0.2189 \\
\hline Environmental Justice & $0 \quad 0$ & 0.0000 \\
\hline
\end{tabular}

\section{Leaf Report}

\section{Response Prob}

\section{Leaf Label}

Financial Component(No)\&Expanded Choice(Yes)

Financial Component(No)\&Expanded Choice(No Effect, No)

Financial Component(Yes)\&Expanded Choice(Yes)\&Political Status(Blue)

Financial Component(Yes)\&Expanded Choice(Yes)\&Political Status(Purple, Red)

Financial Component(Yes)\&Expanded Choice(No, No Effect)

\begin{tabular}{c}
0 \\
0.3448 \\
0.5923 \\
0.5278 \\
0.7845 \\
0.9438 \\
\hline
\end{tabular}

\begin{tabular}{r|}
1 \\
652 \\
\hline 077 \\
\hline 722 \\
155 \\
\hline 562
\end{tabular}

Response Counts

\section{Leaf Label}

Financial Component(No)\&Expanded Choice(Yes)

Financial Component(No)\&Expanded Choice(No Effect, No)

Financial Component(Yes)\&Expanded Choice(Yes)\&Political Status(Blue)

Financial Component(Yes)\&Expanded Choice(Yes)\&Political Status(Purple, Red)

Financial Component(Yes)\&Expanded Choice(No, No Effect)

\section{Fit Details}

\begin{tabular}{|c|c|c|}
\hline Measure & Training & Validation Definition \\
\hline Entropy RSquare & 0.1198 & 0.1040 1-Loglike(model)/Loglike(0) \\
\hline Generalized RSquare & 0.2015 & $0.1634\left(1-(\mathrm{L}(0) / \mathrm{L}(\text { model }))^{\wedge}(2 / \mathrm{n})\right) /\left(1-\mathrm{L}(0)^{\wedge}(2 / \mathrm{n})\right)$ \\
\hline Mean - Log $p$ & 0.5938 & $0.5039 \sum-\log (\rho[i]) / n$ \\
\hline RASE & 0.4540 & $0.4086 \sqrt{ } \sum(y[j]-\rho[j])^{2 / n}$ \\
\hline Mean Abs Dev & 0.4169 & $0.3743 \sum|y[j]-\rho[j]| / n$ \\
\hline Misclassification Rate & 0.3333 & $0.2000 \sum(\rho[j] \neq \rho M a x) / n$ \\
\hline $\mathrm{N}$ & 99 & $20 n$ \\
\hline
\end{tabular}

\begin{tabular}{|c|c|c|c|c|c|}
\hline \multicolumn{6}{|c|}{ Confusion Matrix } \\
\hline \multicolumn{3}{|c|}{ Training } & \multicolumn{3}{|c|}{ Validation } \\
\hline Actual & \multicolumn{2}{|c|}{$\begin{array}{c}\text { Predicted } \\
\text { Count }\end{array}$} & Actual & \multicolumn{2}{|c|}{$\begin{array}{l}\text { Predicted } \\
\text { Count }\end{array}$} \\
\hline Enacted & 0 & 1 & Enacted & 0 & 1 \\
\hline 0 & 52 & 7 & 0 & 14 & 1 \\
\hline 1 & 26 & 14 & 1 & 3 & 2 \\
\hline
\end{tabular}

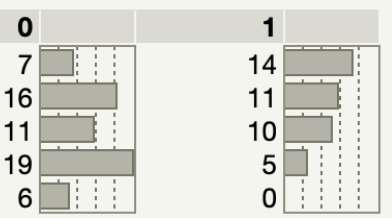

\section{Crossvalidation \\ k-fold -2LogLike RSquare \\ 5 Folded $130.285861 \quad 0.0246$ \\ Overall $116.860319 \quad 0.1198$}

Receiver Operating Characteristic

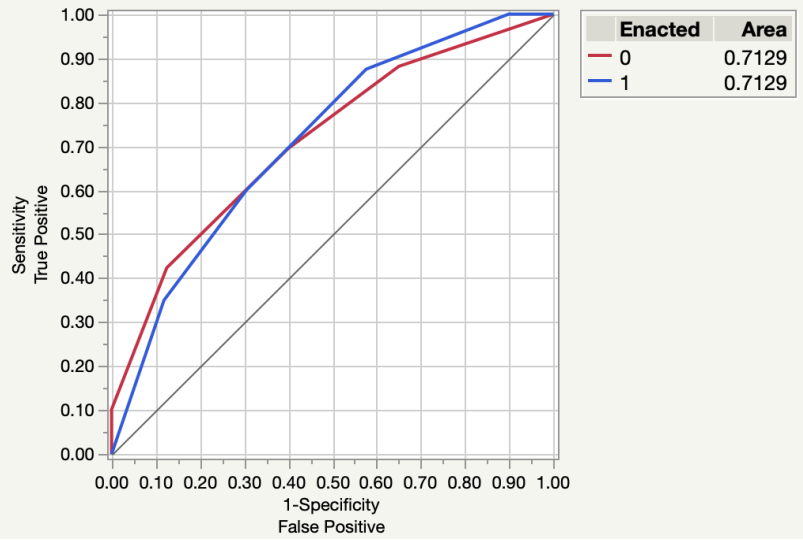

Receiver Operating Characteristic on Validation Data

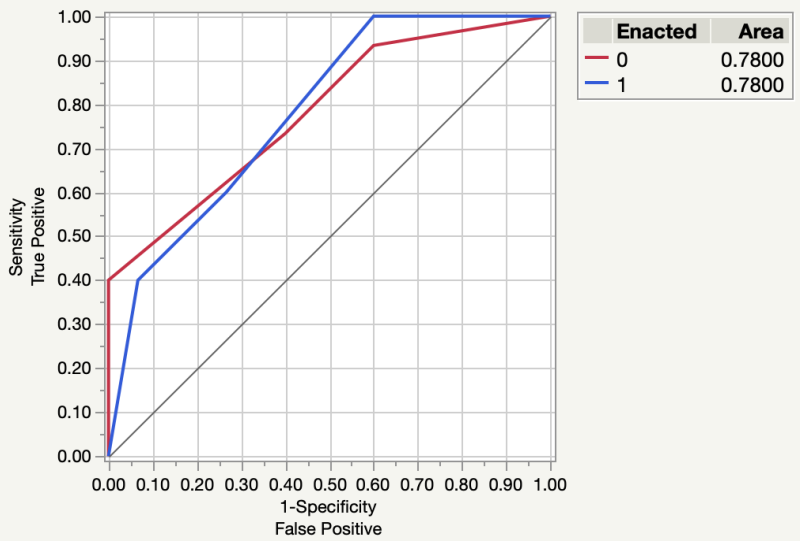


Appendix 5: Leaders in Renewable Energy

\section{US states: wind electricity growth leaders}

\section{Increase in wind electricity, 2010-2019 (GWh)}

Texas

Oklahoma

Kansas

Iowa

Illinois

California

Colorado

Nebraska

North Dakota

Minnesota

Source: Environment America Research \& Policy Center

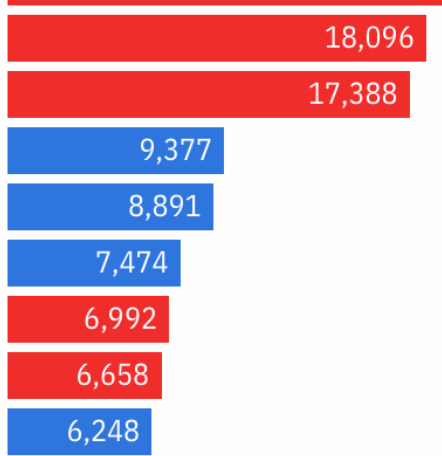

25,075

ENERGYMONITOR 


\section{Other REEE Distribution}

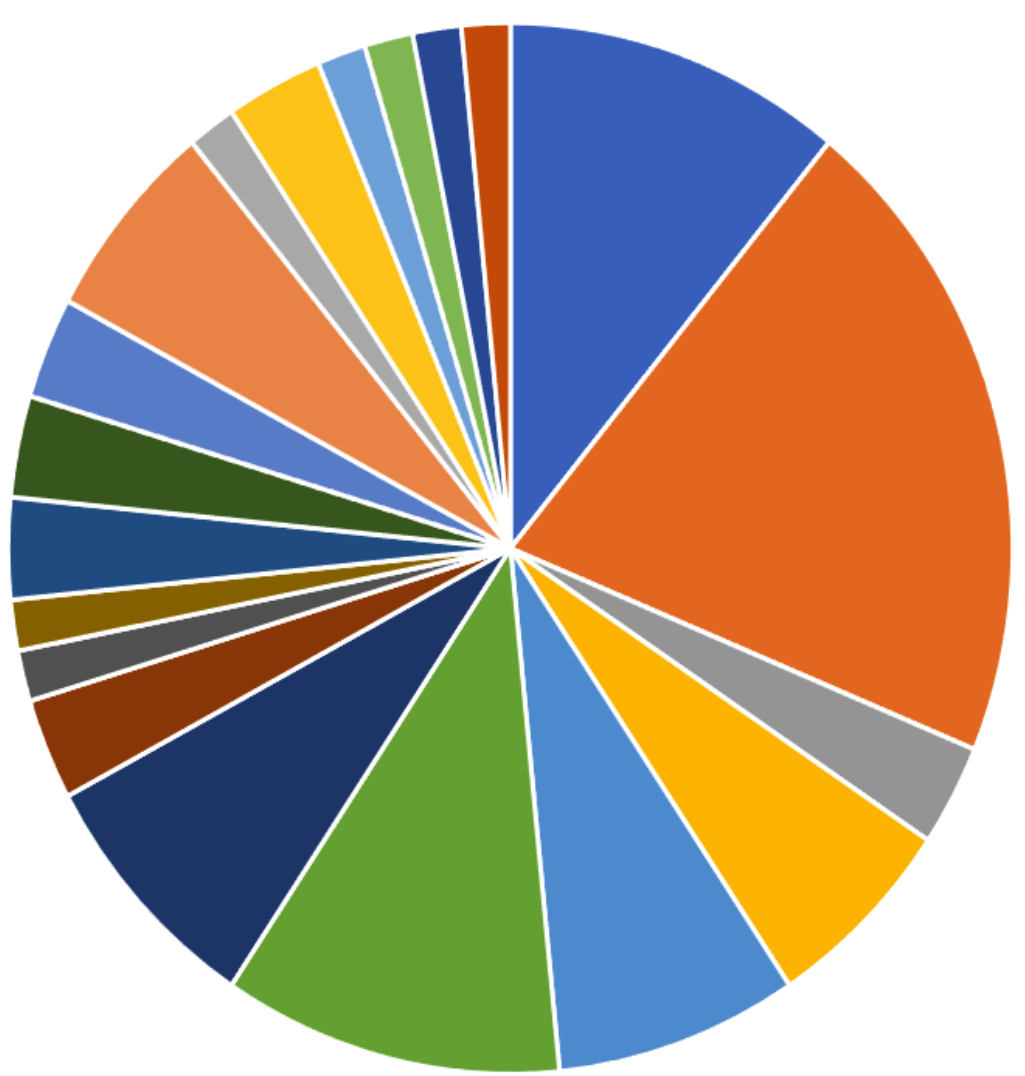

- Task Force

- Pilot Program

- Progress reports (GHG, RPS)

- Investment Planning

- Required to consider RPS

- Consumer info on energy efficient options

- Membership (đimate Alliance and RGGI)

- Underground CO2 storage

- Rapid Transit renewable electricity

- Voluntary emissions bank
- Study

n New Commission or Authority

- Environmental Justice Commission and Definitions

- Utility regulationa and studies

- Variable rate ban

- Recycling infrastructure and end of life management

- Other energy (bioenergy, nud ear)

" Soil and forest health iniriatives

- Voluntary business sustainability

- Contracts 
